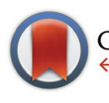

CrossMark

Cite this: Dalton Trans., 2016, 45, 17020

Received 13th August 2016, Accepted 21st September 2016 DOI: $10.1039 / \mathrm{c} 6 \mathrm{dt} 03216 \mathrm{~h}$ www.rsc.org/dalton

\title{
Chromium complexes bearing amidinato- phosphino ligand: synthesis, characterization, and catalytic properties of ethylene tri-/tetramerization and polymerization $\uparrow$
}

\author{
Rui Liu, ${ }^{a}$ Kongtao Zhu, ${ }^{a}$ Xianghong Zhong, ${ }^{\star b}$ Jiancheng Li, ${ }^{a}$ Zhenyu Liu, ${ }^{b}$ \\ Shibing Chen ${ }^{\mathrm{b}}$ and Hongping Zhu*a
}

\begin{abstract}
An amidinato-phosphino ligand $\mathrm{ArN}=\mathrm{C}(\mathrm{R}) \mathrm{NH}\left(\mathrm{o}-\mathrm{Ph}_{2} \mathrm{PC}_{6} \mathrm{H}_{4}\right)\left(\mathrm{Ar}=2,4,6-\mathrm{Me}_{3} \mathrm{C}_{6} \mathrm{H}_{2}, \mathrm{R}=\mathrm{Ph}(\mathbf{1}) ; \mathrm{Ar}=\right.$ 2,6-i $\mathrm{Pr}_{2} \mathrm{C}_{6} \mathrm{H}_{3}, \mathrm{R}=\mathrm{Ph}(\mathbf{2}) ; \mathrm{Ar}=2,6-\mathrm{iPr}_{2} \mathrm{C}_{6} \mathrm{H}_{3}, \mathrm{R}=t \mathrm{Bu}$ (3)) was prepared. The ligand reacted with $\mathrm{CrCl}_{3}(\mathrm{THF})_{3}$ to yield the $\mathrm{N}, \mathrm{P}$-chelation complex $\left[\mathrm{ArNHC}(\mathrm{R})=\mathrm{N}\left(0-\mathrm{Ph}_{2} \mathrm{PC}_{6} \mathrm{H}_{4}\right)\right] \mathrm{CrCl}_{3}(\mathrm{THF})(4-6)$, and the ligand's lithium salt $\mathrm{ArN}=\mathrm{C}(\mathrm{R}) \mathrm{N}\left(\mathrm{O}-\mathrm{Ph}_{2} \mathrm{PC}_{6} \mathrm{H}_{4}\right) \mathrm{Li}$ reacted with the respective $\mathrm{CrCl}_{3}(\mathrm{THF})_{3}$ and $\mathrm{CrCl}_{2}(\mathrm{THF})_{2}$ to give the N,N,P-chelation complexes $\left[\mathrm{ArN}=\mathrm{C}(\mathrm{R}) \mathrm{N}\left(\mathrm{O}-\mathrm{Ph}_{2} \mathrm{PC}_{6} \mathrm{H}_{4}\right)\right] \mathrm{CrCl}_{2}(\mathrm{THF})(\mathbf{7}-\mathbf{8})$ and $\{[\mathrm{ArN}=\mathrm{C}(\mathrm{R}) \mathrm{N}(\mathrm{O}-$ $\left.\left.\left.\mathrm{Ph}_{2} \mathrm{PC}_{6} \mathrm{H}_{4}\right)\right] \mathrm{Cr}(\mu-\mathrm{Cl})\right\}_{2}$ (9-11). Complexes 1-11 were characterized by IR, NMR (for 1-3), EPR (for 4-11) spectroscopy and CHN elemental analysis, of which 3, 5, 8, and $\mathbf{1 1}$ were further studied by X-ray crystallography. Upon activation with an organoaluminum cocatalyst, complexes 4-6 were all catalytically active in ethylene tri-/tetramerization along with ethylene polymerization, and complexes 7-11 functioned as well but in ethylene polymerization. The correlation between the structure and the catalytic properties of the catalyst system is discussed.
\end{abstract}

\section{Introduction}

Chromium catalysts bearing the diphosphazane ligand were found in the earlier parts of this century, first by BP researchers and later by Sasol researchers, which exhibited high activity and excellent selectivity in ethylene oligomerization. ${ }^{1}$ The ligand consists of a [PNP] framework with tunable substituents at both the $\mathrm{N}$ and $\mathrm{P}$ atoms, affording an electronic and steric environment for the $\mathrm{Cr}$ center to facilitate ethylene trimerization or tri-/tetramerization through the formation of ultimate $\mathrm{CrC}_{6}$ or $\mathrm{CrC}_{6} / \mathrm{CrC}_{8}$ metallocycle(s) as the transient state(s). ${ }^{2}$ This offers a route for production of 1-hexene and 1-octene capable of challenging the traditional nonselective ethylene oligomerization ways (usually producing Schulz-Flory distributions of oligomers) $)^{3}$ and others such as pyrolysis of petroleum fractions or waxes. ${ }^{2 h}$ Both 1-hexene and 1-octene

\footnotetext{
${ }^{a}$ State Key Laboratory of Physical Chemistry of Solid Surfaces, National Engineering Laboratory for Green Chemical Productions of Alcohols-Ethers-Esters, College of Chemistry and Chemical Engineering, Xiamen University, Xiamen, 361005, China. E-mail: hpzhu@xmu.edu.cn

${ }^{b}$ Maoming Branch R\&D Institute, SINOPEC, Maoming 525011, China.

E-mail: zhongxh.mmsh@sinopec.com

$\dagger$ CCDC 1471338 (3), 1471337 (5), 1471339 (8) and 1471340 (11). For crystallographic data in CIF or other electronic format see DOI: 10.1039/c6dt03216h
}

are well known as comonomers for manufacturing linear lowdensity polyethylene (LLDPE). ${ }^{4}$ Since then, chromium catalysts bearing various ligands with $\mathrm{P}-\mathrm{N}$ functionality have received considerable attention. A number of P,N-bidentate ligand-chelation chromium catalysts have been synthesized and employed for this catalytic reaction. ${ }^{5}$ Besides the abovementioned selective ethylene oligomerization, nonselective ethylene oligomerization and even ethylene polymerization can also take place by means of these catalysts.

A handful of $\mathrm{P}, \mathrm{N}$-multidentate ligand-based chromium catalysts have also been developed. The ligands of the A-F types employed in these catalysts are shown in Chart 1. Chromium catalysts incorporated by the $\mathbf{A}-{ }^{6}, \mathbf{E}_{-}-{ }^{7}$ or $\mathbf{F}$-type ${ }^{8}$ ligands were found to be active for ethylene trimerization along with polymerization, producing hexenes and polyethylenes. The $\mathbf{B}^{5 b}$ coordinated chromium catalyst worked only for polymerization to give polyethylene whereas the $\mathbf{C}^{9}$ co- $^{-}$ ordinated chromium catalyst effected concomitant nonselective oligomerization and polymerization to generate a series of oligomers and polyethylene waxes. The catalytic behavior of the D-type ${ }^{10}$ ligand chromium catalysts was complex due to change in the variety of either the donor atoms or the substituents on the ligand's skeleton. Products such as oligomers, polyethylene waxes, and/or high molecular weight polyethylenes were produced. 


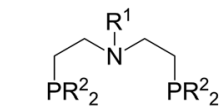

$\mathrm{R}^{1}: \mathrm{H}, \mathrm{Me}, \mathrm{CH}_{2} \mathrm{Ph}, \mathrm{SiMe}_{2} \mathrm{NH} t \mathrm{Bu}$ $\mathrm{R}^{2}$ : Ph, Cy, Et, $i \mathrm{Pr}$

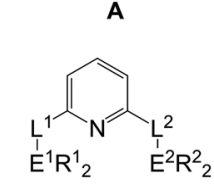

$\mathrm{L}^{1}, \mathrm{~L}^{2}: \mathrm{CH}_{2}, \mathrm{NH}, \mathrm{NPPh}_{2}$ $\mathrm{E}^{1} \mathrm{R}_{2}^{1}: \mathrm{PPh}_{2}, \mathrm{PtBu}_{2}$ $\mathrm{E}^{2} \mathrm{R}_{2}^{2}: \mathrm{PPh}_{2}, \mathrm{PtBu}_{2}, \mathrm{NEt}_{2}$ $\mathrm{L}^{2} \mathrm{E}^{2} \mathrm{R}_{2}^{2}$ : pyrazolyl

D
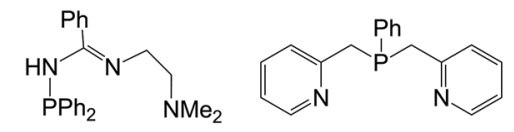

B
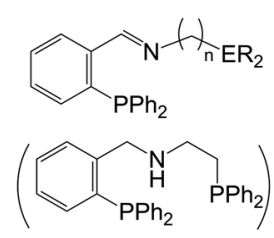

$n: 2-3$

$\mathrm{ER}_{2}: \mathrm{PPh}_{2}, \mathrm{NMe}_{2}$, pyridyl

E

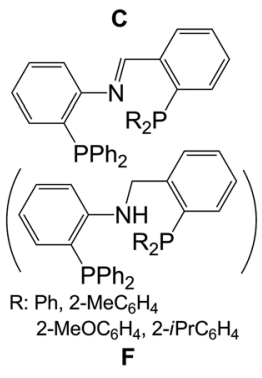

Chart 1 A summary of N,P-multidentate chelation ligands employed to form chromium catalysts for ethylene oligomerization and/or polymerization.

The nature of the ancillary ligand plays a fundamental role in determining the performance of the chromium catalyst. In the above-mentioned examples the catalytic reaction performances of the state-dependent selective or nonselective ethylene oligomerization or ethylene polymerization were, in fact, affected. $^{5-10}$ It is worth noting that some combined catalytic performances such as ethylene polymerization plus selective or nonselective ethylene oligomerization were exhibited especially for the same ligand based chromium catalyst system. ${ }^{7-10}$ The reason for these multiple behaviors may be the formation of multiple active species with chromium in different oxidation states formed under operando conditions. ${ }^{1 a, 2 c, 4 d, 6 b, 11}$ The $\operatorname{Cr}(\mathrm{II})$ state is suggested to respond to nonselective oligomerization ${ }^{12}$ whereas the $\mathrm{Cr}(\mathrm{I}) / \mathrm{Cr}(\mathrm{III})$ couple states are for selective oligomerization. ${ }^{13}$ However, which oxidation state is responsible for polymerization remains unclear. $^{14}$ Nonetheless, studies on these details appear to have been carried out to a lesser extent. ${ }^{3 c, 4 a}$ Herein, we reported a new type of ligand, a phenyl group-connected amidinato-phosphino ligand with the formula $\mathrm{ArN}=\mathrm{C}(\mathrm{R}) \mathrm{NH}$ $\left(o-\mathrm{Ph}_{2} \mathrm{PC}_{6} \mathrm{H}_{4}\right)$ (Ar, R: aryl or alkyl, Scheme 1). This ligand enabled formation of $\mathrm{Cr}$ (III) complexes by either N,P-chelation or N,N,P-chelation prepared under different reaction conditions. Cr(II) complexes with the N,N,P-chelated ligand have also been synthesized. Catalytic tests have shown that in the

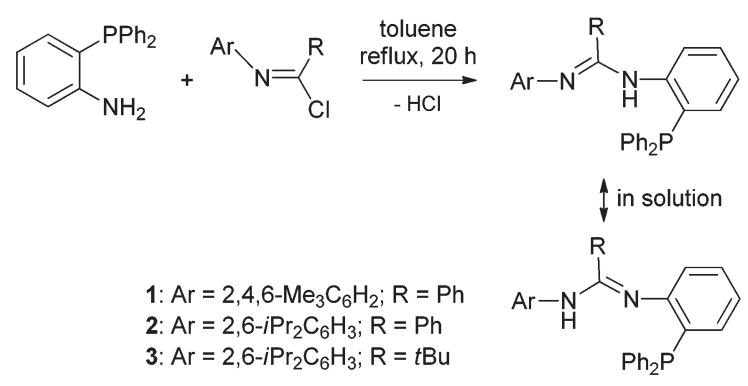

Scheme 1 Synthesis of ligands 1-3. presence of organoaluminum as the cocatalyst, the N,Pchelation $\mathrm{Cr}(\mathrm{III})$ complexes were active in ethylene tri-/tetramerization along with ethylene polymerization whereas the N,N,P-chelation $\mathrm{Cr}$ (III) and $\mathrm{Cr}$ (II) complexes were only active in ethylene polymerization. These results inspire a discussion of the different catalytic performances which probably occur by forming multiple active species from the same ligand stabilized chromium catalyst system.

\section{Results and discussion}

\section{Synthesis and characterization of the amidinato-phosphino ligands and the chromium complexes}

The phenyl group connected amidinato-phosphino ligand has rarely been reported. ${ }^{15}$ Using $o$-diphenylphosphinoaniline as the precursor, ${ }^{16}$ a condensation reaction with imidoyl chloride $\mathrm{ArN}=\mathrm{C}(\mathrm{R}) \mathrm{Cl}$ was proven to be useful for preparation of the target ligand $\mathrm{ArN}=\mathrm{C}(\mathrm{R}) \mathrm{NH}\left(o-\mathrm{Ph}_{2} \mathrm{PC}_{6} \mathrm{H}_{4}\right)\left(\mathrm{Ar}=2,4,6-\mathrm{Me}_{3} \mathrm{C}_{6} \mathrm{H}_{2}\right.$, $\mathrm{R}=\mathrm{Ph}(1) ; \mathrm{Ar}=2,6-\mathrm{iPr}_{2} \mathrm{C}_{6} \mathrm{H}_{3}, \mathrm{R}=\mathrm{Ph}(2) ; \mathrm{Ar}=2,6-\mathrm{iPr}_{2} \mathrm{C}_{6} \mathrm{H}_{3}, \mathrm{R}=$ $t \mathrm{Bu}$ (3)), with elimination of $\mathrm{HCl}$ under reflux conditions in toluene (Scheme 1). Imidoyl chloride can be prepared via initial amination of acylchloride $(\mathrm{RC}(\mathrm{O}) \mathrm{Cl})(\mathrm{R}=t \mathrm{Bu}$ and $\mathrm{Ph})$ using a primary amine $\left(\mathrm{ArNH}_{2}\right)\left(\mathrm{Ar}=2,4,6-\mathrm{Me}_{3} \mathrm{C}_{6} \mathrm{H}_{2}\right.$ and 2,6$\mathrm{iPr}_{2} \mathrm{C}_{6} \mathrm{H}_{3}$ ), followed by dehydroxylation and subsequent chlorination in the presence of thionyl chloride. ${ }^{17}$ Then, both the $\mathrm{Ar}$ and $\mathrm{R}$ groups are easily tuned in the $\mathrm{NCN}_{6} \mathrm{C}_{6} \mathrm{H}_{4}-\mathrm{O}-\mathrm{PPh}_{2}$ scaffold.

Ligands 1-3 were characterized by NMR $\left({ }^{1} \mathrm{H},{ }^{13} \mathrm{C}\right.$, and $\left.{ }^{31} \mathrm{P}\right)$, IR spectroscopy and CHN elemental analysis. The presence of the $\mathrm{PPh}_{2}$ group in 1-3 is indicated by the ${ }^{31} \mathrm{P}$ NMR spectra that show resonances at $\delta-16.3 \mathrm{ppm}$ for $1, \delta-18.2 \mathrm{ppm}$ for 2 , and $\delta-16.1 \mathrm{ppm}$ for 3 . These values are a little downfield compared with that of the precursor $o-\mathrm{Ph}_{2} \mathrm{PC}_{6} \mathrm{H}_{4} \mathrm{NH}_{2}$ $(\delta-21.0 \mathrm{ppm}) .{ }^{13}$ Formation of the amidinato $\mathrm{N}=\mathrm{C}-\mathrm{NH}$ functionality is evidenced from the ${ }^{13} \mathrm{C}$ NMR spectra in which carbon resonances at $\delta 154.0 \mathrm{ppm}$ for $1, \delta 153.8 \mathrm{ppm}$ for 2 , and $\delta 153.9 \mathrm{ppm}$ for 3 are exhibited. The IR spectra display the related $\mathrm{C}=\mathrm{N}$ bond vibrations at $\nu 1619 \mathrm{~cm}^{-1}$ for $\mathbf{1}$, $\nu 1620 \mathrm{~cm}^{-1}$ for 2 , and $\nu 1665 \mathrm{~cm}^{-1}$ for 3 . Moreover, the resonances at $\delta 6.20 \mathrm{ppm}$ for $1, \delta 6.24 \mathrm{ppm}$ for 2 , and $\delta 6.46 \mathrm{ppm}$ for 3 in the ${ }^{1} \mathrm{H}$ NMR spectra are due to the $\mathrm{N} H$ proton. The IR spectra present $\mathrm{NH}$ bands for 1-3 in a characteristic area ( $\nu 3336 \mathrm{~cm}^{-1}$ for $1, \nu 3335 \mathrm{~cm}^{-1}$ for 2 , and $\nu 3399 \mathrm{~cm}^{-1}$ for 3 ). To confirm the composition and structure of the ligand in detail, single crystals of 3 were grown and further studied by $\mathrm{X}$-ray diffraction. As expected, the character of the $\mathrm{NCN}-\mathrm{C}_{6} \mathrm{H}_{4}$ $o-\mathrm{PPh}_{2}$ scaffold in 3 is clearly revealed with the $t \mathrm{Bu}$ group at the $\mathrm{C}$ atom and the 2,6-i $\mathrm{Pr}_{2} \mathrm{C}_{6} \mathrm{H}_{3}$ group at the terminal $\mathrm{N}$ atom (Fig. 1). In this motif, the $\mathrm{N}(1)-\mathrm{C}(1)$ and $\mathrm{N}(2)-\mathrm{C}(1)$ bond lengths are 1.281(2) and 1.379(2) A, respectively. The former bond length falls in the range of those observed in the imine compounds (1.24-1.28 $\AA$ ) ${ }^{18}$ while the latter is comparably shorter than that of the $\mathrm{N}-\mathrm{C}_{\text {aryl }}$ single bond $(1.410(2)$ and $1.427(2) \AA)$. These data indicate that an electronic conjugation over the $\mathrm{N}=\mathrm{C}-\mathrm{N}$ skeleton is formed. It should be mentioned 


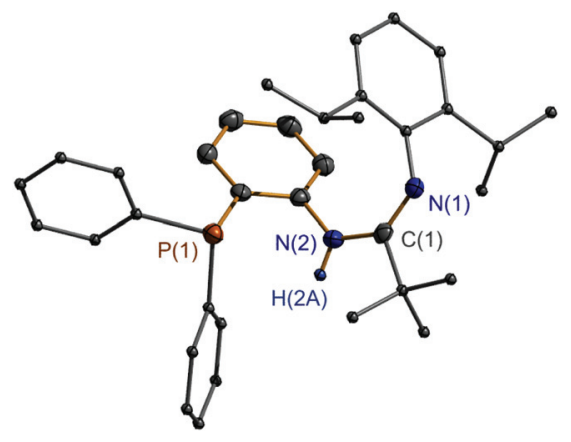

Fig. $1 \mathrm{X}$-ray molecular structure of 3 with thermal ellipsoids at 50\% probability level. All $\mathrm{H}$ atoms, except for that of $\mathrm{NH}$, are omitted for clarity.

that in the ${ }^{1} \mathrm{H}$ NMR spectra of $\mathbf{1 - 3}$, broadening proton resonances were actually observed which implies a slow interchange of the ligand into its resonance form through the $\mathrm{N}=\mathrm{C}-\mathrm{N}$ skeleton in solution (Scheme 1). Similar tautomerization has been observed for the $N$-phosphinoamidine ligand reported by Sydora and coworkers. ${ }^{5 b}$ The latter resonance form is also found in the formation of the $\mathrm{Cr}(\mathrm{III})$ complexes 4-6 (vide infra).

The reactions of 1-3 with $\mathrm{CrCl}_{3}(\mathrm{THF})_{3}$ were each carried out at room temperature (in THF for 1 and 2 and in $\mathrm{CH}_{2} \mathrm{Cl}_{2}$ for 3 ), and complexes 4-6 were readily produced with respective isolated yields of $89 \%, 82 \%$, and $80 \%$ (Scheme 2). Further reactions were performed using $\mathrm{CrCl}_{2}(\mathrm{THF})_{2}$ instead. However, no reaction resulted even we treated the reaction at elevated temperatures and even upon reflux. Complexes 4-6 were characterized by IR spectroscopy which showed that the $\mathrm{N}-\mathrm{H}$ bond remained (the vibration is at $\nu 3165 \mathrm{~cm}^{-1}$ for $\mathbf{4}$, $\nu 3195 \mathrm{~cm}^{-1}$ for 5 , and $\nu 3328 \mathrm{~cm}^{-1}$ for 6). IR bands for the $\mathrm{C}=\mathrm{N}$ bond were found at $\nu 1595 \mathrm{~cm}^{-1}$ for $\mathbf{4}, \nu 1588 \mathrm{~cm}^{-1}$ for $\mathbf{5}$, and $\nu 1588 \mathrm{~cm}^{-1}$ for 6 . Meanwhile, EPR spectral analysis was performed, which gave $g$ values of 4.294 for $\mathbf{4}, 3.902$ for 5 , and 4.646 for 6 , indicative of formation of the $\mathrm{Cr}$ (III) complexes as these data are close to those of other trivalent chromium complexes (3.75-4.38). ${ }^{19}$ Furthermore, complex 5 was studied by X-ray crystallography. The structural analysis clearly demonstrated N,P-bidentate chelation of ligand 2 at the $\mathrm{Cr}(\mathrm{III})$ center with the $\mathrm{NH}$ group away from coordination (Fig. 2). This ligation feature is different from those of the aforementioned $\mathrm{P}, \mathrm{N}, \mathrm{P}$-chelation chromium complexes having the $\mathrm{NH}$ group in the $\mathbf{E}$ and $\mathbf{F}$ types ligands. ${ }^{7,8}$ The $\mathrm{N}(1)-\mathrm{C}(7)$ and $\mathrm{N}(2)-\mathrm{C}(7)$ bond

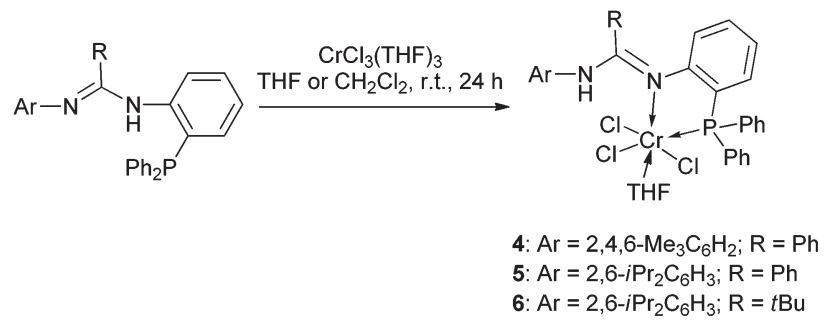

Scheme 2 Synthesis of the N,P-chelation Cr(III) complexes 4-6.

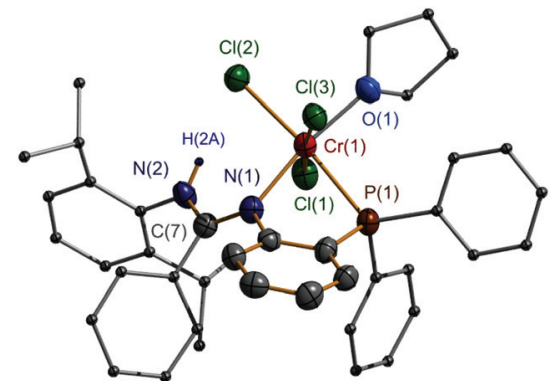

Fig. 2 X-ray molecular structure of $\mathbf{5}$ with thermal ellipsoids at $50 \%$ probability level. All $\mathrm{H}$ atoms, except for that of $\mathrm{NH}$, are omitted for clarity.

lengths are 1.322(6) and 1.337(6) Å, respectively, showing great electronic conjugation over the $\mathrm{N}=\mathrm{C}-\mathrm{N}$ skeleton. The $\mathrm{NH}$ proton facing towards the $\mathrm{Cr}$ center then prevents a bond interaction between the $\mathrm{Cr}$ and the $\mathrm{N}_{\mathrm{NH}}$ atom $(\mathrm{Cr}(1) \cdots \mathrm{N}(2)$ $3.312 \AA)$. In this structure, the $\mathrm{Cr}$ atom is six-coordinate and adopts a distorted octahedral geometry where $\mathrm{P}(1), \mathrm{N}(1), \mathrm{O}(1)$, $\mathrm{Cl}(2)$, and $\operatorname{Cr}(1)$ form a basal plane $(\Delta=0.0098 \AA)$ and $\operatorname{Cl}(1)$ and $\mathrm{Cl}(3)$ are located at the top and bottom apex positions $\left(\mathrm{Cl}(1)-\mathrm{Cr}(1)-\mathrm{Cl}(3) 174.3(1)^{\circ}\right)$.

We further employed a metathesis reaction to prepare the chromium complexes. Treatment of 1-3 with $n \mathrm{BuLi}$ in THF over the temperature range from -78 to $-30{ }^{\circ} \mathrm{C}$ produced the related lithium salts that were not isolated but directly used for reaction with $\mathrm{CrCl}_{3}(\mathrm{THF})_{3}$ over the temperature range from $-78{ }^{\circ} \mathrm{C}$ to room temperature. Complexes 7 and 8 were successfully obtained (Scheme 3), but isolation of a similar complex containing the deprotonated ligand 3 failed, as in the reaction a black suspension was always formed from which it was not possible to obtain the pure target. Still, by this method, complexes 9-11 were readily afforded using $\mathrm{CrCl}_{2}(\mathrm{THF})_{2}$ as the chromium source (Scheme 3).

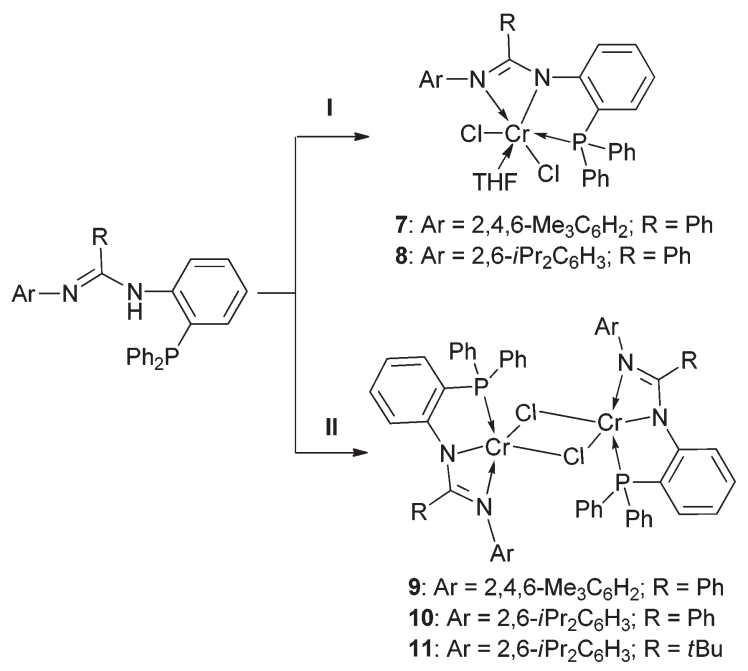

Scheme 3 Synthesis of the N,N,P-chelation $\mathrm{Cr}(\mathrm{III})$ and $\mathrm{Cr}(\mathrm{II})$ complexes 7-11. 
Complexes 7-11 were characterized by IR spectroscopy which revealed the absence of the $\mathrm{N}-\mathrm{H}$ bond vibration for each compound. Moreover, the IR band for the $\mathrm{C}=\mathrm{N}$ bond appeared to be red-shifted $\left(\nu 1578 \mathrm{~cm}^{-1}\right.$ for $7, \nu 1591 \mathrm{~cm}^{-1}$ for $8, \nu 1578 \mathrm{~cm}^{-1}$ for $\mathbf{9}, \nu 1595 \mathrm{~cm}^{-1}$ for 10 , and $\nu 1586 \mathrm{~cm}^{-1}$ for 11) when compared with those of the ligands 1-3. These data are also different from those of complexes 4-6. All of these factors suggest that an N,N,P-coordination mode of the monoanionic ligand at the $\mathrm{Cr}$ atom was formed in $\mathbf{7 - 1 1}$, and this mode is confirmed from X-ray crystallographic analysis of the representative complexes 8 and 11. Furthermore, EPR spectral analysis confirmed the $\mathrm{Cr}$ (III) state in $\mathbf{7}$ and 8, which exhibited $g$ values of 3.912 for 7 and 4.349 for $\mathbf{8}$, both were comparably similar to those of other $\mathrm{Cr}(\mathrm{III})$ complexes $^{19}$ and complexes 4-6. The EPR signals for 9-11 are silent, suggestive of the $\operatorname{Cr}$ (II) state of these complexes, as has been commonly discussed in the other divalent chromium compounds. ${ }^{13 f}$ Due to the different oxidation states of the Cr atoms present in $\mathbf{8}$ and 11, differed molecular structures were exhibited (Fig. 3 and 4). Complex $\mathbf{8}$ is mononuclear with a trivalent chromium center

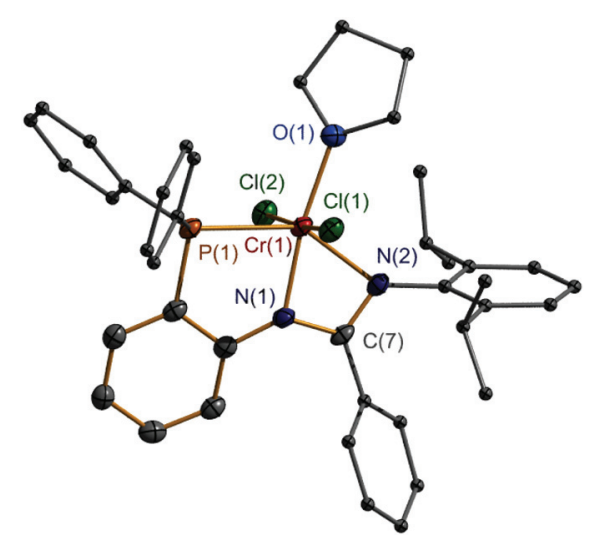

Fig. 3 X-ray molecular structure of 8 with thermal ellipsoids at 50\% probability level. $\mathrm{H}$ atoms are omitted for clarity.

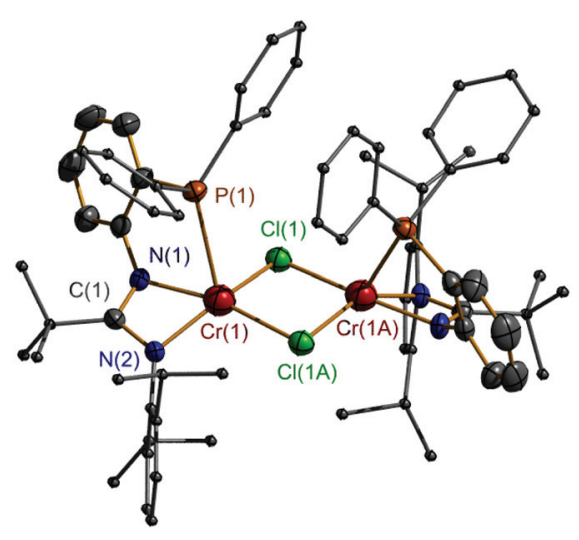

Fig. 4 X-ray molecular structure of 11 with thermal ellipsoids at $50 \%$ probability level. $\mathrm{H}$ atoms are omitted for clarity. Symmetry code for A: $1-x, y,-z+1 / 2$.
Table 1 Selected bond lengths (Å) and angles $\left({ }^{\circ}\right)$ for complexes 3, 5, 8, and 11

\begin{tabular}{lllll}
\hline Comp. & $\mathbf{3}$ & $\mathbf{5}$ & $\mathbf{8}$ & $\mathbf{1 1}$ \\
\hline $\mathrm{N}-\mathrm{C}_{\mathrm{N}=\mathrm{C}-\mathrm{N}}$ & $1.281(2)$ & $1.322(6)$ & $1.313(4)$ & $1.334(4)$ \\
$\mathrm{Cr}-\mathrm{N}$ & $1.379(2)$ & $1.337(6)$ & $1.343(4)$ & $1.344(4)$ \\
& & $2.109(4)$ & $1.971(3)$ & $2.054(3)$ \\
$\mathrm{Cr}-\mathrm{P}$ & & $2.464(2)$ & $2.114(3)$ & $2.045(3)$ \\
$\mathrm{Cr}-\mathrm{Cl}$ & & $2.298(1)$ & $2.299(1)$ & $2.772(1)$ \\
& & $2.323(1)$ & $2.312(1)$ & $2.381(1)$ \\
$\mathrm{Cr}-\mathrm{O}_{\mathrm{THF}}$ & & $2.340(2)$ & & \\
$\mathrm{N}-\mathrm{C}-\mathrm{N}$ & $129.7(2)$ & $2.082(3)$ & $2.054(2)$ & \\
$\mathrm{P}-\mathrm{Cr}-\mathrm{N}$ adj. & & $120.3(4)$ & $110.1(3)$ & $108.3(3)$ \\
$\mathrm{N}-\mathrm{Cr}-\mathrm{N}$ & & $76.3(1)$ & $79.2(1)$ & $71.9(1)$ \\
& & & $64.3(1)$ & $64.1(1)$
\end{tabular}

in a distorted octahedral geometry. The ligand's $\mathrm{N}, \mathrm{N}$, and $\mathrm{P}$ atoms coordinate at the $\mathrm{Cr}$ in a closely meridional arrangement $\left(\Delta_{\mathrm{N}(2) \mathrm{C}(7) \mathrm{N}(1) \mathrm{C}(1) \mathrm{C}(2) \mathrm{P}(1) \mathrm{Cr}(1)}=0.0834 \AA\right)$ and one THF and two $\mathrm{Cl}^{-}$moieties complete the three remaining positions. This structure can be compared to those of the $\mathrm{Cr}$ (III) complexes incorporating the neutral PNP $\left(\mathbf{D},{ }^{10} \mathbf{E},{ }^{7}\right.$ and $\mathbf{F},{ }^{8}$ Chart 1) and PNN ( $\mathbf{B},{ }^{5 b}$ Chart 1$)$ type ligands. In contrast, complex 11 is dinuclear having two divalent chromium centers. Its formation is probably due to a steric structural compromise of the monomeric form of $\left[2,6-\mathrm{iPr}_{2} \mathrm{C}_{6} \mathrm{H}_{3} \mathrm{~N}=\mathrm{C}(t \mathrm{Bu}) \mathrm{N}\left(o-\mathrm{Ph}_{2} \mathrm{PC}_{6} \mathrm{H}_{4}\right)\right] \mathrm{CrCl}$, as in this form the $\mathrm{Cr}$ is four-coordinate and strongly prone to adopting a square-planar geometry. ${ }^{20}$ In 11 , the $\operatorname{Cr}(1) \cdots \operatorname{Cr}(1 \mathrm{~A})$ separation is 3.410 (1) $\AA$, indicative of almost non-bonding between them. Then, each $\mathrm{Cr}$ center adopts a distorted squarepyramidal geometry in which two $\mathrm{N}$ and two $\mathrm{Cl}$ atoms form the base $\left(\Delta_{\mathrm{N}(1) \mathrm{N}(2) \operatorname{Cr}(1) \mathrm{Cl}(1) \mathrm{Cl}(1 \mathrm{~A})}=0.1865 \AA\right)$ and the $\mathrm{P}$ atom stands at the apex.

Selected bond parameters on the $\mathrm{N}=\mathrm{C}-\mathrm{N}$ moiety in $\mathbf{3}, \mathbf{5}, \mathbf{8}$, and $\mathbf{1 1}$ are summarized in Table 1 . Once they have formed the metal complexes, the parameters for the $\mathrm{N}=\mathrm{C}-\mathrm{N}$ skeleton changed dramatically. This indicates a strong bonding interaction between either the $\mathrm{Cr}$ (II) or the $\mathrm{Cr}$ (III) center with the amidinato-phosphino ligand. The $\mathrm{Cr}-\mathrm{N}$ bond lengths appear over a close range $(1.971(3)-2.114(3) \AA)$. Within the $\mathrm{CrCN}_{2}$ four-membered chelating rings of 8 and $\mathbf{1 1}$, the $\mathrm{N}-\mathrm{Cr}-\mathrm{N}$ bond angles are $64.3(1)^{\circ}$ and $64.1(1)^{\circ}$, respectively. In addition, the $\mathrm{Cr}-\mathrm{P}$ bond lengths appear close to those in the $\mathrm{Cr}(\mathrm{III})$ complexes (2.464(2) $\AA$ in 5 and 2.493(1) $\AA$ in 8), but they are significantly shorter than that in the Cr(II) complex 11 (2.772(1) $\AA$ ) due to the different geometries adopted. The $\mathrm{N}-\mathrm{Cr}-\mathrm{P}$ bond angles within the $\mathrm{CrC}_{2} \mathrm{NP}$ five-membered chelation ring are $76.3(1)^{\circ}$ and $79.2(1)^{\circ}$ in the $\mathrm{Cr}(\mathrm{III})$ complexes 5 and 8, respectively, and this angle is found to be $71.9(1)^{\circ}$ in the $\operatorname{Cr}$ (II) complex 11.

\section{Ethylene oligomerization/polymerization test on 4-11}

In combination with methylalumoxane (MAO) as the cocatalyst, complex 4 acted as a catalyst to produce oligomers along with polymers when exposed to ethylene at $40 \mathrm{bar}$ and $50{ }^{\circ} \mathrm{C}$ in toluene as a solvent. The catalytic activity appeared to change 
a little when different $\mathrm{Al}: \mathrm{Cr}$ molar ratios were employed (13.2, 15.1, and $12.5 \mathrm{~kg}$ of products per $\mathrm{g}$ of $\mathrm{Cr}$ per $\mathrm{h}$ for the $\mathrm{Al}: \mathrm{Cr}$ ratios of $800: 1,600: 1$, and $400: 1$, entries $3-5$ in Table 2). These activities are comparable to those for the $\mathrm{Ph}_{2} \mathrm{PN}(\mathrm{Me})-2-\mathrm{C}_{5} \mathrm{H}_{4} \mathrm{~N} / \mathrm{CrCl}_{3}(\mathrm{THF})_{3} / \mathrm{MAO}$ system $\quad(\mathrm{Al}: \mathrm{Cr}$ of $500: 1,30$ or 50 bar ethylene, and $60^{\circ} \mathrm{C}$; 8.1-38.9 $\mathrm{kg}$ of products per $\mathrm{g}$ of $\mathrm{Cr}$ per $\mathrm{h}),{ }^{5 c}$ but lower than those for the $\left[\mathrm{R}_{2}^{3} \mathrm{PNC}\left(\mathrm{R}^{2}\right) \mathrm{NHR}^{1}\right] \mathrm{CrCl}_{3}(\mathrm{THF}) / \mathrm{MMAO}-3 \mathrm{~A}$ system ( $\mathrm{Al}: \mathrm{Cr}$ of $400-800,48$ or 60 bar ethylene, and $50-70{ }^{\circ} \mathrm{C}$; 70.1-1051.9 kg of products per $\mathrm{g}$ of $\mathrm{Cr}$ per $\mathrm{h}) .{ }^{5 b}$ The polymers produced were analyzed to have molecular weights in the range of 1.14-1.97 $\times$ $10^{5} \mathrm{~g} \mathrm{~mol}^{-1}$. Corresponding differential scanning calorimetry (DSC) measurements gave melting points of $135-141^{\circ} \mathrm{C}$, indicating the linear character of these polymers. ${ }^{21}$ The oligomers were analyzed and found to be composed of $1-\mathrm{C}_{6}$ and $1-\mathrm{C}_{8}$ olefins as the dominant parts (66-78\%) together with other cyclic $\mathrm{C}_{6}$ components (methylcyclopentane and methylenecyclopentane, 10-19\%) and $\mathrm{C}_{10+}$ species (10-14\%). These data arise as a result of selective ethylene tri-/tetramerization. This catalytic mode has been extensively studied using Sasol's diphosphazane ligand chromium catalysts and other P,N-chelation chromium catalysts. ${ }^{1-3,5}$ It was noted that the proportion of $\mathrm{C}_{8}: \mathrm{C}_{6}$ changed as well with the $\mathrm{Al}: \mathrm{Cr}$ ratio $(0.48: 1$ for $800: 1,1.20: 1$ for $600: 1$, and $0.50: 1$ for $400: 1)$. This result, along with the aforementioned activities, implies a nonnegligible influence of the $\mathrm{Al}: \mathrm{Cr}$ molar ratio used in this system. The ratio may relate to the formation of catalytically active site(s) over the course of the interactions between 4 and MAO (vide infra). Nonetheless, in these catalytic reactions an $\mathrm{Al}: \mathrm{Cr}$ molar ratio of $600: 1$ is the best ratio to achieve the higher activity as well as the yield of the $1-\mathrm{C}_{8}$ product.

Further investigation found that an alteration of the $\mathrm{Al}$ cocatalyst had an effect on the reaction result as well. When using either $\mathrm{AlMe}_{3}$ or $\mathrm{Et}_{2} \mathrm{AlCl}$ instead, there was almost no activity (entries 6 and 7). However, a combination of $\mathrm{AlMe}_{3}$ and $\mathrm{Et}_{2} \mathrm{AlCl}$ led to a reaction, producing polymers with a significantly broad PDI (73.9) although the distribution of the oligomers generated was comparable to that of entry 5. But, the activity of this reaction decreased remarkably $(7.2 \mathrm{~kg}$ of products per $\mathrm{g}$ of $\mathrm{Cr}$ per h, entry 8). Gambarotta, Duchateua and coworkers have reported no activity for the catalyst system of $\left[\mathrm{Ph}_{2} \mathrm{PN}(\mathrm{Cy}) \mathrm{PPh}_{2}\right] \mathrm{CrCl}_{3}$ activated by $\mathrm{AlMe}_{3}$. But in the additional presence of MAO or other activators the catalyst system worked. ${ }^{22}$ Similar work has also been reported by the groups of McGuinness, Tooze, and Overett. ${ }^{23}$ Then, a cooperation between $\mathrm{AlMe}_{3}$ and $\mathrm{Et}_{2} \mathrm{AlCl}$ may be responsible for getting 4 to work, although the activity appears lower.

On the basis of the conditions used in entry 3 , increasing the concentration of the catalyst to double produced more products as expected, but the activity was calculated to decrease a little (10.6 kg of products per $\mathrm{g}$ of $\mathrm{Cr}$ per h, entry 9), although the results including the $M_{\mathrm{w}}$, PDI, and DSC data for the

Table 2 Ethylene oligomerization/polymerization results ${ }^{a}$

\begin{tabular}{|c|c|c|c|c|c|c|c|c|c|c|c|c|c|c|}
\hline \multirow[b]{2}{*}{ Entry } & \multirow[b]{2}{*}{ Cat. } & \multirow[b]{2}{*}{ Co-cat. } & \multirow[b]{2}{*}{$\mathrm{Al}: \mathrm{Cr}$} & \multirow[b]{2}{*}{$\begin{array}{l}T \\
\left({ }^{\circ} \mathrm{C}\right)\end{array}$} & \multirow[b]{2}{*}{$\begin{array}{l}P \\
\text { (bar) }\end{array}$} & \multirow[b]{2}{*}{$\begin{array}{l}\text { Time } \\
\text { (min) }\end{array}$} & \multirow[b]{2}{*}{$\begin{array}{l}\text { Yield (polym. + } \\
\text { oligom., g) }\end{array}$} & \multirow[b]{2}{*}{ Act. ${ }^{b}$} & \multicolumn{3}{|l|}{ Polym. } & \multicolumn{3}{|c|}{$\begin{array}{l}\text { Oligom. distribution }{ }^{f} \\
\text { (wt\%) }\end{array}$} \\
\hline & & & & & & & & & $\begin{array}{l}M_{\mathrm{W}}{ }^{c} \\
\left(10^{5} \mathrm{~g} \mathrm{~mol}^{-1}\right)\end{array}$ & $\mathrm{PDI}^{d}$ & $\mathrm{MPt}^{e}$ & $\mathrm{C}_{6}\left(1-\mathrm{C}_{6}\right)$ & $\mathrm{C}_{8}\left(1-\mathrm{C}_{8}\right)$ & $\mathrm{C}_{10+}$ \\
\hline $1^{g}$ & $\mathrm{CrCl}_{3}(\mathrm{THF})_{3}$ & MAO & 600 & 50 & 40 & 30 & $0.18+0$ & 0.7 & nd & nd & nd & - & - & - \\
\hline $2^{h}$ & $\mathrm{CrCl}_{2}(\mathrm{THF})_{2}$ & MAO & 600 & 50 & 40 & 30 & $0.15+0$ & 0.6 & nd & nd & nd & - & - & - \\
\hline 3 & 4 & MAO & 600 & 50 & 40 & 30 & $1.94+1.98$ & 15.1 & 1.97 & 9.2 & 135 & $40(75)$ & $48(100)$ & 12 \\
\hline 4 & 4 & MAO & 800 & 50 & 40 & 30 & $1.69+1.75$ & 13.2 & 1.14 & 2.6 & 140 & $58(65)$ & $28(100)$ & 14 \\
\hline 5 & 4 & MAO & 400 & 50 & 40 & 30 & $1.59+1.65$ & 12.5 & 1.21 & 2.9 & 141 & $60(68)$ & $30(100)$ & 10 \\
\hline 6 & 4 & $\mathrm{Et}_{2} \mathrm{AlCl}$ & 500 & 50 & 40 & 30 & Trace & 0 & - & - & - & - & - & - \\
\hline 7 & 4 & $\mathrm{Me}_{3} \mathrm{Al}$ & 500 & 50 & 40 & 30 & Trace & 0 & - & - & - & - & - & - \\
\hline $8^{i}$ & 4 & $\mathrm{Et}_{2} \mathrm{AlCl} / \mathrm{Me}_{3} \mathrm{Al}$ & 500 & 50 & 40 & 30 & $0.92+0.95$ & 7.2 & 1.11 & 73.9 & 137 & $60(69)$ & $29(100)$ & 11 \\
\hline $9^{j}$ & 4 & MAO & 600 & 50 & 40 & 30 & $2.65+2.85$ & 10.6 & 2.24 & 8.9 & 135 & $41(78)$ & $47(100)$ & 12 \\
\hline 10 & 4 & MAO & 600 & 70 & 40 & 30 & $2.44+2.48$ & 18.9 & 2.07 & 7.9 & 143 & $52(65)$ & $33(100)$ & 15 \\
\hline 11 & 4 & MAO & 600 & 30 & 40 & 30 & $1.46+1.46$ & 11.2 & 5.66 & 13.6 & 145 & $40(62)$ & $49(100)$ & 11 \\
\hline 12 & 4 & MAO & 600 & 50 & 30 & 30 & $1.45+1.49$ & 11.3 & 1.78 & 7.4 & 138 & $43(67)$ & $46(100)$ & 11 \\
\hline 13 & 4 & MAO & 600 & 50 & 20 & 30 & $1.31+1.35$ & 10.2 & 1.51 & 3.6 & 136 & $41(68)$ & $45(100)$ & 14 \\
\hline 14 & 4 & MAO & 600 & 50 & 40 & 60 & $4.02+3.88$ & 15.2 & 1.45 & 4.6 & 133 & $41(78)$ & $49(100)$ & 10 \\
\hline 15 & 4 & MAO & 600 & 50 & 40 & 120 & $7.89+7.78$ & 15.1 & 1.54 & 7.6 & 133 & $42(75)$ & $47(100)$ & 11 \\
\hline 16 & 4 & MAO & 600 & 50 & 40 & 180 & $10.3+9.25$ & 12.5 & 1.87 & 5.9 & 134 & $42(72)$ & $45(100)$ & 13 \\
\hline 17 & 4 & MAO & 600 & 50 & 40 & 300 & $12.4+8.26$ & 7.9 & 1.58 & 6.5 & 134 & $40(76)$ & $45(100)$ & 15 \\
\hline 18 & 5 & MAO & 600 & 50 & 40 & 30 & $1.40+1.46$ & 11.0 & 1.67 & 7.4 & 133 & $58(65)$ & $29(100)$ & 13 \\
\hline 19 & 6 & MAO & 600 & 50 & 40 & 30 & $1.33+1.38$ & 10.4 & 5.91 & 93.5 & 133 & $56(67)$ & $30(100)$ & 14 \\
\hline 20 & 7 & MAO & 600 & 50 & 40 & 30 & $3.55+$ trace & 13.7 & 1.87 & 5.9 & 134 & - & - & - \\
\hline 21 & 8 & MAO & 600 & 50 & 40 & 30 & $1.70+$ trace & 6.5 & 2.45 & 13.3 & 134 & - & - & - \\
\hline 22 & 9 & MAO & 600 & 50 & 40 & 30 & $3.35+$ trace & 12.9 & 3.85 & 4.6 & 133 & - & - & - \\
\hline 23 & 10 & MAO & 600 & 50 & 40 & 30 & $2.10+$ trace & 8.1 & 2.46 & 10.7 & 133 & - & - & - \\
\hline 24 & 11 & MAO & 600 & 50 & 40 & 30 & $1.75+$ trace & 6.7 & 2.58 & 120 & 132 & - & - & - \\
\hline
\end{tabular}

${ }^{a}$ General reaction conditions: $70 \mathrm{~mL}$ toluene, $10 \mu \mathrm{mol} \mathrm{Cr}$ complex, 30 minutes. ${ }^{b} \mathrm{~kg}$ of products per $\mathrm{g}$ of $\mathrm{Cr}$ per h. ${ }^{c}$ Determined by GPC relative to polystyrene standards. ${ }^{d}$ Polydispersity index (PDI) $=M_{\mathrm{w}} / M_{\mathrm{n}} \cdot{ }^{e}$ Determined by DSC at a heating rate of $10^{\circ} \mathrm{C}$ min ${ }^{-1} .{ }^{f}$ Weight percentage of liquid fraction. ${ }^{g} 10 \mu \mathrm{mol} \mathrm{CrCl}(\mathrm{THF})_{3} \cdot{ }^{h} 10 \mu \mathrm{mol} \mathrm{CrCl} 2(\mathrm{THF})_{2} \cdot{ }^{i} \mathrm{Et}_{2} \mathrm{AlCl} / \mathrm{Me}_{3} \mathrm{Al}=1: 1(\mathrm{~mol} / \mathrm{mol}) .{ }^{j} 20 \mu \mathrm{mol} \mathrm{Cr}$ complex. 
polymer and the distribution data for the oligomer are similar to those in entry 3 . The higher concentration of the catalyst has a close relation to the formation of the number of real catalytic sites. It has been well indicated that under a steady concentration of the catalyst, catalytic performance often depends on the reaction temperature as well as the ethylene pressure. ${ }^{24}$ This catalyst system showed decreased reaction activity with decreasing ethylene pressure, but little change was observed for the above-mentioned characters of both the polymers and oligomers produced $(11.3$ and $10.2 \mathrm{~kg}$ of products per $\mathrm{g}$ of $\mathrm{Cr}$ per $\mathrm{h}$ at 30 and 20 bar, entries 12 and 13, reespectively). Keeping the ethylene pressure at $40 \mathrm{bar}$, and altering the temperature to $30{ }^{\circ} \mathrm{C}$ decreased the activity down to $11.2 \mathrm{~kg}$ of products per $\mathrm{g}$ of $\mathrm{Cr}$ per h (entry 11) whereas at $70{ }^{\circ} \mathrm{C}$ the activity rose to $18.9 \mathrm{~kg}$ of products per $\mathrm{g}$ of $\mathrm{Cr}$ per $\mathrm{h}$ (entry 10). Meanwhile, the $\mathrm{C}_{8}: \mathrm{C}_{6}$ ratio of the oligomers changed dramatically with the temperature $\left(1.23: 1\right.$ at $30{ }^{\circ} \mathrm{C}$ and $0.63: 1$ at $70{ }^{\circ} \mathrm{C}$ versus $1.20: 1$ at $50{ }^{\circ} \mathrm{C}$ ). Low temperature substantially favors the formation of the $\mathrm{CrC}_{8}$-metallocyclic transient state that results from the insertion of one ethylene molecule into the $\mathrm{CrC}_{6}$-metallocycle intermediate, as has been extensively discussed. ${ }^{1,2,24}$ To evaluate the effectiveness of the system, an experiment with a longer running time of 4/MAO (Al: $\mathrm{Cr}$ of $600: 1$ ) at 40 bar ethylene and $50{ }^{\circ} \mathrm{C}$ was carried out. In the first $2 \mathrm{~h}$ the activity was retained (15.2 and $15.1 \mathrm{~kg}$ of products per $\mathrm{g}$ of $\mathrm{Cr}$ per $\mathrm{h}$ within $1 \mathrm{~h}$ and $2 \mathrm{~h}$, entries 14 and 15, respectively). By extending the time to $3 \mathrm{~h}$ (12.5 kg of products per $\mathrm{g}$ of $\mathrm{Cr}$ per $\mathrm{h}$, entry 16) and $5 \mathrm{~h}$ (7.9 kg of products per $\mathrm{g}$ of $\mathrm{Cr}$ per h, entry 17 ) the activity appeared to decrease gradually. However, the features of the oligomer and polymer products produced showed little change.

Complexes 5 and 6 both possess a ligand-metal chelation structure similar to that of $\mathbf{4}$ and investigation of their catalytic properties was accomplished by controlling the reaction temperature at $50{ }^{\circ} \mathrm{C}$ and ethylene pressure at 40 bar in the presence of MAO (Al: $\mathrm{Cr}$ of $600: 1)$. As a result, different activities were exhibited (11.0 and $10.4 \mathrm{~kg}$ of products per $\mathrm{g}$ of $\mathrm{Cr}$ per h, entries 18 and 19) when compared with that for $\mathbf{4}$ under the same conditions (entry 3). Moreover, in the oligomer products the $\mathrm{C}_{6}$ components increased to $58 \%$ and $56 \%$, respectively while the $\mathrm{C}_{8}$ part dropped to $29 \%$ and $30 \%$. The polymer products showed differences with respect to the $M_{\mathrm{w}}$, PDI, and MPt values as well. Obviously, variation of the $\mathrm{R}$ and $\mathrm{Ar}$ substituents on the respective $\mathrm{C}$ and $\mathrm{N}$ atoms of the ligand backbone has an influence on the catalytic result.

Also under the above conditions, complexes 7-11 were tested. To our surprise, only ethylene polymerization catalysis functioned, all producing polymers without the oligomers (entries 20-24), even though we had further screened the reaction by using greater amounts of the complex and/or MAO as well as by increasing the reaction temperature and/or ethylene pressure. In light of these results, it is worth noting that the same ligand-ligated $\mathrm{Cr}(\mathrm{III})$ and $\mathrm{Cr}(\mathrm{II})$ complexes 7 and $\mathbf{9}$ give close activities (13.7 and $12.9 \mathrm{~kg}$ of products per $\mathrm{g}$ of $\mathrm{Cr}$ per $\mathrm{h}$, entries 20 and 22). Moreover, the characteristics of the polymers were similar. The same case is also observed for complexes 8 and 10 ( 6.5 and $8.1 \mathrm{~kg}$ of products per $\mathrm{g}$ of $\mathrm{Cr}$ per h, entries 21 and 23). But, the results differed between the 7 (or 9)/MAO versus 8 (or 10)/MAO systems.

The P,P- or P,N-bidentate chelation chromium catalyst systems have been well known to effect the selective ethylene tri-/tetramerization catalysis that produces the $1-\mathrm{C}_{6}$ and $1-\mathrm{C}_{8}$ dominant and $\mathrm{C}_{10+}$ parts. In these systems, ethylene polymerization was sometimes observed, but produced fewer polymers. ${ }^{1 b, 2,5}$ Our experiments show that the 4 (5 and 6)/MAO systems produce oligomers and polymers of approximately equal amounts while the $7(\mathbf{8}, \mathbf{9}, \mathbf{1 0}$, and 11)/MAO systems generate only the polymers. ${ }^{25}$ This suggests that in the 4 (5 and 6)/MAO systems, besides ethylene tri-/tetramerization, the polymerization reaction is not neglected. Structural analysis has indicated the difference between complexes 4-6 and 7-11 where the former complexes feature an N,P-chelation of the ligand at the $\mathrm{Cr}$ center while the latter ones feature $\mathrm{N}, \mathrm{N}, \mathrm{P}-\mathrm{chelation}$. Sydora and coworkers have reported that the $N$-phosphinoamidine N,P-chelation $\mathrm{Cr}(\mathrm{III})$ complex/MMAO-3A system initiated selective ethylene tri-/tetramerization while the related N,N,P-chelation $\mathrm{Cr}(\mathrm{III})$ complex/MMAO-3A system resulted in polymerization although the polymers were produced in a trace amounts. ${ }^{5 b}$

Gambarotta and coworkers have reported a deprotonation reaction of the ligand's $\mathrm{NH}$ group in the chromium complexes by organoaluminum compounds. ${ }^{10 b}$ We have also found a deprotonation reaction from model reactions using 4 with $\mathrm{MAO}$ or $\mathrm{AlMe}_{3}$, as indicated by the absence of the NH IR band, by measuring the data of the product upon removal of all volatiles after the reaction, although an isolation of the pure species was not successful. Then, we speculate that the formation of two types of active species in the 4/MAO system is responsible for the multiple catalytic performances. One could be the N,P-chelation chromium complex but with an aluminum-containing moiety attached at the $\mathrm{N}$ atom replacing the original $\mathrm{H}$ group ${ }^{11 g}$ and the other could be the N,N,P-chelation chromium complex comparable to that resulting from the 7 (or 9)/MAO system. The former can catalyze the ethylene tri-/tetramerization reaction but the latter enables ethylene polymerization. Similar cases are also possible for the same ligand ligated chromium systems of 5/MAO versus 8 (or 10)/MAO as well as those of 6/MAO versus 11/MAO.

\section{Conclusions}

In summary, phenyl group-connected amidinato-phosphino ligands 1-3 have been prepared. Three types of complexes including N,P-chelation $\mathrm{Cr}(\mathrm{III})$ (4-6), N,N,P-chelation $\mathrm{Cr}(\mathrm{III})$ (7-8) and $\mathrm{Cr}(\mathrm{II})$ (9-11) complexes have been subsequently prepared through different synthetic routes. Upon activation with MAO, all of these metal complexes are catalytically active. Complexes 4-6 each catalyze the ethylene tri-/tetramerization reaction along with polymerization while complexes 7-11 enable only polymerization. Complexes 4-6 all contain an 
additional $\mathrm{NH}$ group in the ligand backbone and react with MAO to form two, probably different, active sites for the catalytic function of the respective ethylene tri-/tetramerization and polymerization reactions.

\section{Experimental}

\section{Materials and methods}

All manipulation of air- and moisture-sensitive compounds was carried out using Schlenk techniques or in an argon-filled MBRAUN glove box. Toluene, $n$-hexane, and tetrahydrofuran were pre-dried over fine sodium wire and then refluxed with sodium/potassium benzophenone under nitrogen prior to use. $\mathrm{CDCl}_{3}$ was degassed and dried over $\mathrm{CaH}_{2} \cdot{ }^{1} \mathrm{H}(400 \mathrm{MHz}),{ }^{13} \mathrm{C}$ (100 MHz), and ${ }^{31} \mathrm{P}(162 \mathrm{MHz})$ NMR spectra were recorded on a Bruker Avance II $400 \mathrm{MHz}$ spectrometer. IR spectra were measured on a Nicolet 380 spectrometer. All continuous-wave EPR spectra were recorded on an X-band Bruker EMX spectrometer operating at $100 \mathrm{kHz}$ field modulation, $20 \mathrm{~mW}$ microwave power, and equipped with a high-sensitivity cavity (4119HS-LC). The $g$ values were determined using a DPPH standard. Melting points of the compounds were measured in a sealed glass tube using a Büchi-540 instrument. Elemental analysis was performed on a Thermo Quest Italia SPA EA 1110 instrument. The molecular weight and polydispersity indices (PDI) of the polymer samples were determined through PL-GPC 220 type high-temperature $\left(150{ }^{\circ} \mathrm{C}\right)$ gel-permeation chromatography. The sample concentration was set in $0.10 \mathrm{mg}$ $\mathrm{mL}^{-1}$, and 1,2,4-trichlorobenzene (TCB) stabilized with $0.0125 \%$ butylated hydroxytoluene (BHT) was used as an

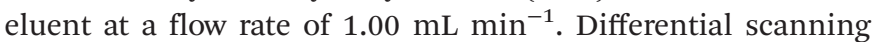
calorimetry (DSC) measurements were performed on a PerkinElmer DSC 8000 instrument under an $\mathrm{N}_{2}$ atmosphere in which the samples were treated upon heating and then cooling at the same rate of $10{ }^{\circ} \mathrm{C} \mathrm{min}^{-1}$. Liquid products were analyzed by GC-FID using a GC-950 with an HP-1 capillary column $(60 \mathrm{~m} \times 0.25 \mathrm{~mm})$. Methylaluminoxane (MAO, 10\% solution in toluene), $\mathrm{AlMe}_{3}(1.0 \mathrm{M}$ solution in hexanes) and $\mathrm{Et}_{2} \mathrm{AlCl}$ (2.0 M solution in hexanes) were purchased from J \& $\mathrm{K}$ Chemical Technology Co. Polymerization grade ethylene was obtained from Linde Industrial Gases Co. Compounds $\mathrm{CrCl}_{3}(\mathrm{THF})_{3}$ and $\mathrm{CrCl}_{2}(\mathrm{THF})_{2}{ }^{26} \mathrm{ArN}=\mathrm{C}(\mathrm{R}) \mathrm{Cl} \quad(\mathrm{Ar}=2,4,6-$ $\mathrm{Me}_{3} \mathrm{C}_{6} \mathrm{H}_{2}, \mathrm{R}=\mathrm{Ph} ; \mathrm{Ar}=2,6-\mathrm{iPr}_{2} \mathrm{C}_{6} \mathrm{H}_{3}, \mathrm{R}=\mathrm{Ph} ; \mathrm{Ar}=2,6-\mathrm{iPr}_{2} \mathrm{C}_{6} \mathrm{H}_{3}$, $\mathrm{R}=t \mathrm{Bu}),{ }^{17}$ and $o-\mathrm{Ph}_{2} \mathrm{PC}_{6} \mathrm{H}_{4} \mathrm{NH}_{2}{ }^{16}$ were prepared by following procedures detailed in the literature.

2,4,6-Me $\mathrm{Me}_{6} \mathrm{H}_{2} \mathbf{N}=\mathbf{C}(\mathbf{P h}) \mathbf{N H}\left(\boldsymbol{o}-\mathrm{Ph}_{2} \mathbf{P C}_{6} \mathrm{H}_{4}\right)$ (1). A mixture of $2,4,6-\mathrm{Me}_{3} \mathrm{C}_{6} \mathrm{H}_{2} \mathrm{~N}=\mathrm{C}(\mathrm{Ph}) \mathrm{Cl} \quad(5.86 \quad \mathrm{~g}, \quad 22.71 \quad \mathrm{mmol}) \quad$ and $o-\mathrm{Ph}_{2} \mathrm{PC}_{6} \mathrm{H}_{4} \mathrm{NH}_{2}(6.30 \mathrm{~g}, 22.71 \mathrm{mmol})$ in toluene $(200 \mathrm{~mL})$ was heated at reflux for $20 \mathrm{~h}$. After workup, the toluene solvent was removed and the residue was dissolved in ethanol $(100 \mathrm{~mL})$. By neutralization using aqueous $\mathrm{NH}_{3}(25 \%, 90 \mathrm{~mL})$, a beige solid of $\mathbf{1}$ was precipitated and collected by filtration. Recrystallization from toluene $(60 \mathrm{~mL})$ at $-20{ }^{\circ} \mathrm{C}$ for $3 \mathrm{~d}$ gave spectroscopically pure 1 (8.94 g, 79\%). Mp: $151-152{ }^{\circ} \mathrm{C}$. ${ }^{1} \mathrm{H}$ NMR (400 MHz, $\left.\mathrm{CDCl}_{3}, 298 \mathrm{~K}, \mathrm{ppm}\right): \delta 7.54-6.50$ (m, $21 \mathrm{H}$,
$\mathrm{C}_{6} H_{2}, \mathrm{C}_{6} H_{4}$ and $\left.\mathrm{C}_{6} H_{5}\right), 6.20(\mathrm{~s}, 1 \mathrm{H}, \mathrm{NH}), 2.25(\mathrm{~s}, 3 \mathrm{H}, 4-\mathrm{Me})$, $2.11(\mathrm{~s}, 6 \mathrm{H}, 2,6-\mathrm{Me}) .{ }^{13} \mathrm{C}$ NMR $\left(100 \mathrm{MHz}, \mathrm{CDCl}_{3}, 298 \mathrm{~K}, \mathrm{ppm}\right)$ : $\delta 154.0(C=\mathrm{N}), 143.2\left(\mathrm{~d}, J_{\mathrm{PC}}=19.8 \mathrm{~Hz}\right), 143.1,135.2,134.9$ $\left(\mathrm{d}, J_{\mathrm{PC}}=9.6 \mathrm{~Hz}\right), 133.9\left(\mathrm{~d}, J_{\mathrm{PC}}=20 \mathrm{~Hz}\right), 133.0,131.8,130.0$ $\left(\mathrm{d}, J_{\mathrm{PC}}=11.9 \mathrm{~Hz}\right), 129.8,129.2,129.0,128.9,128.8,128.5$, 128.2, 127.7, 124.8, $124.1\left(C_{6} \mathrm{H}_{2}, C_{6} \mathrm{H}_{4}\right.$ and $\left.C_{6} \mathrm{H}_{5}\right), 18.8(4-M e)$, 17.9 (2,6-Me). ${ }^{31} \mathrm{P}$ NMR (162 MHz, $\left.\mathrm{CDCl}_{3}, 298 \mathrm{~K}, \mathrm{ppm}\right)$ : $\delta$-16.3. IR (KBr plate, Nujol mull, $\mathrm{cm}^{-1}$ ): $\nu 3336(\mathrm{~N}-\mathrm{H}), 1619$ $(\mathrm{C}=\mathrm{N})$. Anal. Calcd for $\mathrm{C}_{34} \mathrm{H}_{31} \mathrm{~N}_{2} \mathrm{P}\left(M_{\mathrm{r}}=498.60\right)$ : C, 81.90; $\mathrm{H}, 6.27$; N, 5.62. Found: C, 81.76; H, 6.23; N, 5.51.

2,6-i $\mathrm{Pr}_{2} \mathrm{C}_{6} \mathbf{H}_{3} \mathbf{N}=\mathbf{C}(\mathbf{P h}) \mathbf{N H}\left(o-\mathbf{P h}_{2} \mathbf{P C}_{6} \mathbf{H}_{4}\right)$ (2). A mixture of 2,6$\operatorname{iPr}_{2} \mathrm{C}_{6} \mathrm{H}_{3} \mathrm{~N}=\mathrm{C}(\mathrm{Ph}) \mathrm{Cl}(14.98 \mathrm{~g}, 50 \mathrm{mmol})$ and $o-\mathrm{Ph}_{2} \mathrm{PC}_{6} \mathrm{H}_{4} \mathrm{NH}_{2}$ $(13.87 \mathrm{~g}, 50 \mathrm{mmol})$ in toluene $(200 \mathrm{~mL})$ was heated at reflux for $20 \mathrm{~h}$. After workup, the toluene solvent was removed and the residue was dissolved in ethanol $(100 \mathrm{~mL})$. By neutralization using aqueous $\mathrm{NH}_{3}(25 \%, 90 \mathrm{~mL})$, an off-white solid was precipitated and collected by filtration to gave spectroscopically pure $2(23.0 \mathrm{~g}, 85 \%)$. Mp: $156-157{ }^{\circ} \mathrm{C} .{ }^{1} \mathrm{H}$ NMR $(400 \mathrm{MHz}$, $\left.\mathrm{CDCl}_{3}, 298 \mathrm{~K}, \mathrm{ppm}\right): \delta 7.50-6.48\left(\mathrm{~m}, 22 \mathrm{H}, \mathrm{C}_{6} H_{3}, \mathrm{C}_{6} H_{4}\right.$ and $\left.\mathrm{C}_{6} H_{5}\right), 6.24(\mathrm{~s}, 1 \mathrm{H}, \mathrm{N} H), 3.05$ (br, $\left.2 \mathrm{H}, \mathrm{CHMe}_{2}\right), 1.14(\mathrm{br}, 12 \mathrm{H}$, $\left.\mathrm{CHMe}_{2}\right) \cdot{ }^{13} \mathrm{C}$ NMR $\left(100 \mathrm{MHz}, \mathrm{CDCl}_{3}, 298 \mathrm{~K}, \mathrm{ppm}\right): \delta 153.8$ $(C=\mathrm{N}), 138.5,135.6,134.9\left(\mathrm{~d}, J_{\mathrm{PC}}=9.4 \mathrm{~Hz}\right), 133.9\left(\mathrm{~d}, J_{\mathrm{PC}}=\right.$ $19.8 \mathrm{~Hz}), 133.2,129.7,129.2,128.7\left(\mathrm{~d}, J_{\mathrm{PC}}=7.2 \mathrm{~Hz}\right), 128.2$, $124.3,124.0,123.6,123.2\left(C_{6} \mathrm{H}_{3}, C_{6} \mathrm{H}_{4}\right.$ and $\left.C_{6} \mathrm{H}_{5}\right), 28.1$ $\left(\mathrm{CHMe}_{2}\right), 23.9\left(\mathrm{CHMe}_{2}\right) .{ }^{31} \mathrm{P}$ NMR $\left(162 \mathrm{MHz}, \mathrm{CDCl}_{3}, 298 \mathrm{~K}\right.$, ppm): $\delta$-18.2. IR (KBr plate, Nujol mull, $\left.\mathrm{cm}^{-1}\right): \nu 3335(\mathrm{~N}-\mathrm{H})$, $1620(\mathrm{C}=\mathrm{N})$. Anal. Calcd for $\mathrm{C}_{37} \mathrm{H}_{37} \mathrm{~N}_{2} \mathrm{P}\left(M_{\mathrm{r}}=540.68\right)$ : C, 82.19; H, 6.71; N, 5.18. Found: C, 81.88; H, 6.67; N, 5.06.

2,6-iPr ${ }_{2} \mathrm{C}_{6} \mathbf{H}_{3} \mathbf{N}=\mathbf{C}(t \mathrm{Bu}) \mathbf{N H}\left(\boldsymbol{o}-\mathrm{Ph}_{2} \mathbf{P C}_{6} \mathbf{H}_{4}\right)$ (3). A mixture of 2,6${ }_{i P r} \mathrm{C}_{6} \mathrm{H}_{3} \mathrm{~N}=\mathrm{C}(t \mathrm{Bu}) \mathrm{Cl}(2.80 \mathrm{~g}, 10 \mathrm{mmol})$ and $o-\mathrm{Ph}_{2} \mathrm{PC}_{6} \mathrm{H}_{4} \mathrm{NH}_{2}$ $(2.77 \mathrm{~g}, 10 \mathrm{mmol})$ in toluene $(80 \mathrm{~mL})$ was heated at reflux for $20 \mathrm{~h}$ under $\mathrm{N}_{2}$ flow. After workup, the toluene solvent was removed and the residue was extracted with $n$-hexane $(15 \mathrm{~mL})$. The extract was stored in a freezer $\left(-20^{\circ} \mathrm{C}\right)$ for $3 \mathrm{~d}$ to give colorless crystals of 3 (3.80 g, 72\%). Mp: $121-122{ }^{\circ} \mathrm{C} .{ }^{1} \mathrm{H}$ NMR $\left(400 \mathrm{MHz}, \mathrm{CDCl}_{3}, 298 \mathrm{~K}, \mathrm{ppm}\right): \delta 7.33-6.60\left(\mathrm{~m}, 22 \mathrm{H}, \mathrm{C}_{6} H_{3}\right.$, $\mathrm{C}_{6} H_{4}$ and $\left.\mathrm{C}_{6} H_{5}\right), 6.46(\mathrm{~s}, 1 \mathrm{H}, \mathrm{NH}), 3.28$ (br, $\left.2 \mathrm{H}, \mathrm{C} H \mathrm{Me}_{2}\right), 1.29$ (br, $\left.12 \mathrm{H}, \mathrm{CHMe} e_{2}\right), 1.21\left(\mathrm{~s}, 9 \mathrm{H}, \mathrm{CMe}_{3}\right) .{ }^{13} \mathrm{C}$ NMR $(100 \mathrm{MHz}$, $\left.\mathrm{CDCl}_{3}, 298 \mathrm{~K}, \mathrm{ppm}\right): \delta 153.9(C=\mathrm{N}), 145.1,141.6,135.9,135.4$, $134.2\left(\mathrm{~d}, J_{\mathrm{PC}}=20.1 \mathrm{~Hz}\right), 131.9,129.4,128.9,128.2\left(\mathrm{~d}, J_{\mathrm{PC}}=\right.$ $23.9 \mathrm{~Hz}), 125.5,124.9,123.8,122.0,121.2\left(C_{6} \mathrm{H}_{3}, C_{6} \mathrm{H}_{4}\right.$ and $\left.\mathrm{C}_{6} \mathrm{H}_{5}\right), 40.0\left(\mathrm{CMe}_{3}\right), 29.2\left(\mathrm{CMe}_{3}\right), 28.4\left(\mathrm{CHMe}_{2}\right), 23.1\left(\mathrm{CHMe}_{2}\right)$. ${ }^{31} \mathrm{P}$ NMR (162 MHz, $\left.\mathrm{CDCl}_{3}, 298 \mathrm{~K}, \mathrm{ppm}\right): \delta-16.1$. IR ( $\mathrm{KBr}$ plate, Nujol mull, cm $\left.{ }^{-1}\right): \nu 3399(\mathrm{~N}-\mathrm{H}), 1665(\mathrm{C}=\mathrm{N})$. Anal. Calcd for $\mathrm{C}_{35} \mathrm{H}_{41} \mathrm{~N}_{2} \mathrm{P}\left(M_{\mathrm{r}}=520.69\right)$ : C, 80.73; H, 7.94; N, 5.38. Found: C, 80.25; H, 7.56; N, 5.15.

$\left.\left[2,4,6-\mathrm{Me}_{3} \mathrm{C}_{6} \mathrm{H}_{2} \mathrm{NHC}(\mathrm{Ph})=\mathrm{N}\left(o-\mathrm{Ph}_{2} \mathrm{PC}_{6} \mathrm{H}_{4}\right)\right] \mathrm{CrCl}_{3}(\mathrm{THF})\right] \quad$ (4). A solution of $1(0.50 \mathrm{~g}, 1.0 \mathrm{mmol})$ in THF $(15 \mathrm{~mL})$ was added to a suspension of $\mathrm{CrCl}_{3}(\mathrm{THF})_{3}(0.37 \mathrm{~g}, 1.0 \mathrm{mmol})$ in THF $(15 \mathrm{~mL})$ at room temperature. The mixture was stirred for $24 \mathrm{~h}$. Using filtration to remove trace amounts of insoluble solid, the filtrate was evaporated to dryness under reduced pressure. The residue was collected and washed with $n$-hexane $(5 \mathrm{~mL})$ to give complex 4 as a grey green solid (0.65 g, 89\%). Mp: $264{ }^{\circ} \mathrm{C}$ (decomp.). IR ( $\mathrm{KBr}$ plate, Nujol mull, $\left.\mathrm{cm}^{-1}\right): \nu 3165(\mathrm{~N}-\mathrm{H})$, $1595(\mathrm{C}=\mathrm{N})$. EPR (100 kHz field, $90 \mathrm{~K}): g=4.294$. Anal. Calcd 
for $\mathrm{C}_{38} \mathrm{H}_{39} \mathrm{Cl}_{3} \mathrm{CrN}_{2} \mathrm{OP}\left(M_{\mathrm{r}}=729.06\right)$ : C, 62.60; H, 5.39; N, 3.84. Found: C, 62.27; H, 5.86; N, 3.49.

$\left.\left[2,6-\mathrm{PPr}_{2} \mathrm{C}_{6} \mathrm{H}_{3} \mathrm{NHC}(\mathrm{Ph})=\mathrm{N}\left(\boldsymbol{o}-\mathrm{Ph}_{2} \mathrm{PC}_{6} \mathrm{H}_{4}\right)\right] \mathrm{CrCl}_{3}(\mathrm{THF})\right]$ Complex 5 was prepared in a similar manner to that of 4 but, in the preparation, $2(0.54 \mathrm{~g}, 1.0 \mathrm{mmol})$ was used instead of 1 . Complex 5 was obtained as a dark-green solid (0.63 g, 82\%). Mp: $265^{\circ} \mathrm{C}$ (decomp.). IR (KBr plate, Nujol mull, $\left.\mathrm{cm}^{-1}\right): \nu 3195$ $(\mathrm{N}-\mathrm{H}), \nu 1588(\mathrm{C}=\mathrm{N})$. EPR (100 kHz field, $90 \mathrm{~K}): g=3.902$. Anal. Calcd for $\mathrm{C}_{41} \mathrm{H}_{45} \mathrm{Cl}_{3} \mathrm{CrN}_{2} \mathrm{OP}\left(M_{\mathrm{r}}=771.14\right)$ C, 63.86; H, 5.88; N, 3.63. Found: C, 64.10; H, 6.01; N, 3.46. X-ray quality single-crystals of $5 \cdot 0.5 \mathrm{THF}$ were obtained from recrystallization in a $\mathrm{THF} / n$-hexane $(5 \mathrm{v} / 1 \mathrm{v})$ solution at $-20^{\circ} \mathrm{C}$ for $3 \mathrm{~d}$.

$\left.\left[2,6-\mathrm{iPr}_{2} \mathrm{C}_{6} \mathrm{H}_{3} \mathrm{NHC}(\mathrm{tBu})=\mathbf{N}\left(o-\mathrm{Ph}_{2} \mathrm{PC}_{6} \mathrm{H}_{4}\right)\right] \mathrm{CrCl}_{3}(\mathrm{THF})\right]$ (6). A solution of $\mathrm{CrCl}_{3}(\mathrm{THF})_{3}(0.37 \mathrm{~g}, 1.0 \mathrm{mmol})$ in $\mathrm{CH}_{2} \mathrm{Cl}_{2}(15 \mathrm{~mL})$ was added to a solution of $3(0.50 \mathrm{~g}, 1.0 \mathrm{mmol})$ in $\mathrm{CH}_{2} \mathrm{Cl}_{2}$ $(15 \mathrm{~mL})$ at room temperature, and the mixture was stirred for $24 \mathrm{~h}$. After workup, the $\mathrm{CH}_{2} \mathrm{Cl}_{2}$ solvent was removed under reduced pressure and the residue was collected and washed with $n$-hexane to give complex 6 as a yellow-green solid ( $0.60 \mathrm{~g}$, 80\%). Mp: $236{ }^{\circ} \mathrm{C}$ (decomp.). IR (KBr plate, Nujol mull, $\mathrm{cm}^{-1}$ ): $\nu 3328(\mathrm{~N}-\mathrm{H}), \nu 1588(\mathrm{C}=\mathrm{N})$. EPR (100 kHz field, $90 \mathrm{~K}): g=$ 4.646. Anal. Calcd for $\mathrm{C}_{39} \mathrm{H}_{49} \mathrm{Cl}_{3} \mathrm{CrN}_{2} \mathrm{OP}\left(M_{\mathrm{r}}=751.15\right)$ : C, 62.36; H, 6.58; N, 3.73. Found: C, 62.25; H, 6.43; N, 3.88.

$\left[2,4,6-\mathrm{Me}_{3} \mathrm{C}_{6} \mathrm{H}_{2} \mathbf{N}=\mathbf{C}(\mathbf{P h}) \mathbf{N}\left(o-\mathrm{Ph}_{2} \mathrm{PC}_{6} \mathrm{H}_{4}\right)\right] \mathrm{CrCl}_{2}(\mathrm{THF}) \quad$ (7). A solution of $n \mathrm{BuLi}$ (2.4 M in $n$-hexane, $0.42 \mathrm{~mL}, 1.0 \mathrm{mmol}$ ) was added dropwise to a solution of $1(0.50 \mathrm{~g}, 1.0 \mathrm{mmol})$ in THF $(30 \mathrm{~mL})$ at $-78{ }^{\circ} \mathrm{C}$. The mixture was gently warmed to $-30{ }^{\circ} \mathrm{C}$ within $2 \mathrm{~h}$ and stirred at this temperature for an additional $0.5 \mathrm{~h}$ to give the lithium salt of $\mathbf{1}$. This solution was cooled again to $-78{ }^{\circ} \mathrm{C}$ and to it a suspension of $\mathrm{CrCl}_{3}(\mathrm{THF})_{3}(0.37 \mathrm{~g}$, $1.0 \mathrm{mmol})$ in THF $(15 \mathrm{~mL})$ was added dropwise. The mixture was warmed gently to room temperature within $4 \mathrm{~h}$ and then stirred for additional $12 \mathrm{~h}$. After workup, all volatiles were removed under reduced pressure and the residue was extracted with toluene $(20 \mathrm{~mL})$. The extract was evaporated to dryness to give complex 7 as a dark-green solid (0.56 g, 81\%). Mp: $252{ }^{\circ} \mathrm{C}$ (decomp.). IR ( $\mathrm{KBr}$ plate, Nujol mull, $\left.\mathrm{cm}^{-1}\right): \nu 1578(\mathrm{C}=\mathrm{N})$. EPR $(100 \mathrm{kHz}$ field, $90 \mathrm{~K}): g=3.912$. Anal. Calcd for $\mathrm{C}_{38} \mathrm{H}_{38} \mathrm{Cl}_{2} \mathrm{CrN}_{2} \mathrm{OP}\left(M_{\mathrm{r}}=692.60\right)$ : C, 65.90; H, 5.53; N, 4.04. Found: C, 65.78; H, 5.62; N, 3.99.

$\left[2,6-\mathrm{iPr}_{2} \mathrm{C}_{6} \mathrm{H}_{3} \mathrm{~N}=\mathrm{C}(\mathrm{Ph}) \mathbf{N}\left(o-\mathrm{Ph}_{2} \mathrm{PC}_{6} \mathrm{H}_{4}\right)\right] \mathrm{CrCl}_{2}$ (THF) Complex 8 was prepared in a similar manner to that of 7 but, in the preparation, $2(0.54 \mathrm{~g}, 1.0 \mathrm{mmol})$ was used instead of 1 . Complex 8 was obtained as a dark-green solid (0.59 g, 86\%). Mp: $233{ }^{\circ} \mathrm{C}$ (decomp.). IR (KBr plate, Nujol mull, $\mathrm{cm}^{-1}$ ): $\nu 1591$ $(\mathrm{C}=\mathrm{N})$. EPR (100 kHz field, $90 \mathrm{~K}): g=4.439$. Anal. Calcd for $\mathrm{C}_{41} \mathrm{H}_{44} \mathrm{Cl}_{2} \mathrm{CrN}_{2} \mathrm{OP}\left(M_{\mathrm{r}}=734.68\right): \mathrm{C}, 67.03 ; \mathrm{H}, 6.04 ; \mathrm{N}, 3.81$. Found: C, 66.99; H, 6.10; N, 3.79. X-ray quality single-crystals of 8.2.5 toluene were obtained from recrystallization in a toluene $/ n$-hexane $(3 \mathrm{v} / 1 \mathrm{v})$ solution at $-20^{\circ} \mathrm{C}$ for $1 \mathrm{~d}$.

$\left\{\left[2,4,6-\mathrm{Me}_{3} \mathrm{C}_{6} \mathrm{H}_{2} \mathbf{N}=\mathbf{C}(\mathrm{Ph}) \mathbf{N}\left(o-\mathrm{Ph}_{2} \mathrm{PC}_{6} \mathrm{H}_{4}\right)\right] \mathrm{Cr}(\boldsymbol{\mu}-\mathrm{Cl})\right\}_{2}$ Complex 9 was prepared in a similar manner to that of 7 but, in the preparation, $\mathrm{CrCl}_{2}(\mathrm{THF})_{2}(0.27 \mathrm{~g}, 1.0 \mathrm{mmol})$ was used instead of $\mathrm{CrCl}_{3}(\mathrm{THF})_{3}$. Complex 9 was obtained as a yellowgreen solid (0.48 g, 82\%). Mp: $215^{\circ} \mathrm{C}$ (decomp.). IR (KBr plate, Nujol mull, $\left.\mathrm{cm}^{-1}\right): \nu 1578(\mathrm{C}=\mathrm{N})$. EPR (100 kHz field, $\left.90 \mathrm{~K}\right)$ : silent. Anal. Calcd for $\mathrm{C}_{68} \mathrm{H}_{60} \mathrm{Cl}_{2} \mathrm{Cr}_{2} \mathrm{~N}_{4} \mathrm{P}_{2} \quad\left(M_{\mathrm{r}}=1170.08\right)$ : C, 69.80; H, 5.17; N, 4.79. Found: C, 69.65; H, 5.26; N, 4.56.

$\left\{\left[2,6-\mathrm{iPr}_{2} \mathrm{C}_{6} \mathrm{H}_{3} \mathbf{N}=\mathbf{C}(\mathrm{Ph}) \mathbf{N}\left(\boldsymbol{o}-\mathrm{Ph}_{2} \mathrm{PC}_{6} \mathrm{H}_{4}\right)\right] \mathrm{Cr}(\boldsymbol{\mu}-\mathrm{Cl})\right\}_{2} \quad$ (10). Complex $\mathbf{1 0}$ was prepared in a similar manner to that of 7 but, in the preparation, $2(0.54 \mathrm{~g}, 1.0 \mathrm{mmol})$ and $\mathrm{CrCl}_{2}(\mathrm{THF})_{2}$ $(0.27 \mathrm{~g}, 1.0 \mathrm{mmol})$ were used instead of the respective 1 and $\mathrm{CrCl}_{3}(\mathrm{THF})_{3}$. Complex 10 was obtained as a green solid (0.54 g, 86\%). Mp: $230{ }^{\circ} \mathrm{C}$ (decomp.). IR ( $\mathrm{KBr}$ plate, Nujol mull, $\mathrm{cm}^{-1}$ ): $\nu 1595(\mathrm{C}=\mathrm{N})$. EPR (100 kHz field, $90 \mathrm{~K})$ : silent. Anal. Calcd for $\mathrm{C}_{74} \mathrm{H}_{72} \mathrm{Cl}_{2} \mathrm{Cr}_{2} \mathrm{~N}_{4} \mathrm{P}_{2}\left(M_{\mathrm{r}}=1254.24\right)$ : C, 70.86; H, 5.79; N, 4.47. Found: C, 70.68; H, 5.64; N, 4.23.

$\left\{\left[2,6-\mathrm{PP}_{2} \mathrm{C}_{6} \mathrm{H}_{3} \mathbf{N}=\mathbf{C}(t \mathrm{Bu}) \mathbf{N}\left(o-\mathrm{Ph}_{2} \mathrm{PC}_{6} \mathrm{H}_{4}\right)\right] \mathrm{Cr}(\boldsymbol{\mu}-\mathrm{Cl})\right\}_{2} \quad$ (11). Complex 11 was prepared in a similar manner to that of 7 but, in the preparation, $3(0.52 \mathrm{~g}, 1.0 \mathrm{mmol})$ and $\mathrm{CrCl}_{2}(\mathrm{THF})_{2}$ $(0.27 \mathrm{~g}, 1.0 \mathrm{mmol})$ were used instead of the respective $\mathbf{1}$ and $\mathrm{CrCl}_{3}(\mathrm{THF})_{3}$. Complex 11 was obtained as a dark-green solid (0.50 g, 82\%). Mp: $186^{\circ} \mathrm{C}$ (decomp.). IR (KBr plate, Nujol mull, $\left.\mathrm{cm}^{-1}\right): \nu 1586(\mathrm{C}=\mathrm{N})$. EPR (100 kHz field, $\left.90 \mathrm{~K}\right)$ : silent. Anal. Calcd for $\mathrm{C}_{70} \mathrm{H}_{80} \mathrm{Cl}_{2} \mathrm{Cr}_{2} \mathrm{~N}_{4} \mathrm{P}_{2}\left(M_{\mathrm{r}}=1214.26\right)$ : C, 69.24; H, 6.64; N, 4.61. Found: C, 69.45; H, 6.54; N, 4.46. X-ray quality singlecrystals of $\mathbf{1 1 . 4}$ toluene were obtained from recrystallization in a toluene $/ n$-hexane $(3 \mathrm{v} / 1 \mathrm{v})$ solution at $-20^{\circ} \mathrm{C}$ for $3 \mathrm{~d}$.

\section{X-ray crystallographic analysis}

The crystals were mounted on a glass fiber using an oil drop method and quickly placed under a low temperature $(173 \mathrm{~K})$ atmosphere. Crystallographic data was collected on an Oxford Gemini S Ultra system. During the measurements, graphitemonochromatic Mo- $K_{\alpha}$ radiation $(\lambda=0.71073 \AA)$ was used for compounds 3, 5, and 11 while $\mathrm{Cu}-\mathrm{K}_{\alpha}$ radiation $(\lambda=1.54178 \AA)$ was employed for compound 8. Absorption corrections were applied using a spherical harmonics program (multi-scan type). All structures were solved by direct methods $\left(\right.$ SHELXS-96) ${ }^{27}$ and refined against $F^{2}$ using SHELXL-97. ${ }^{28}$ In general, the non-hydrogen atoms were located by difference Fourier synthesis and refined anisotropically, and hydrogen atoms were included using a riding model with $U_{\text {iso }}$ tied to the $U_{\text {iso }}$ of the parent atoms unless otherwise specified.

\section{General procedure for catalytic reaction}

The catalytic reaction was carried out in a $300 \mathrm{~mL}$ stainless steel autoclave equipped with a mechanical stirrer, temperature controller and internal cooling system. In a typical experiment, the reactor was heated to $100{ }^{\circ} \mathrm{C}$ under vacuum for $5 \mathrm{~h}$ to maximize the removal of air and moisture inside and then cooled to room temperature prior to use. After flushing with nitrogen gas three times, the catalyst solution (in $20 \mathrm{~mL}$ solvent), co-catalyst (MAO), and solvent were injected in turn into the autoclave. The reactor was pressurized with ethylene and then heated to the desired temperature. After the reaction, the ethylene feed was stopped and the reactor was quickly cooled to $\sim 2{ }^{\circ} \mathrm{C}$ through a $\mathrm{H}_{2} \mathrm{O} /$ glycol low temperature cycling system. By depressurization, the reaction was quenched with a $10 \% \mathrm{HCl} /$ ethanol solution. The liquid product was dried over anhydrous sodium sulfate and then GC-FID analysis was performed. The solid product was dried overnight in an oven at 
$50{ }^{\circ} \mathrm{C}$ to a constant weight and high-temperature GPC analysis was performed.

\section{Acknowledgements}

This work is supported by the National Natural Science Foundation of China (21473142), the National Basic Research Program of China (2012CB821704), and the Program for Innovative Research Teams in Chinese Universities (12DZ2260400, 2013B019 and IRT_14R31).

\section{Notes and references}

1 (a) A. Carter, S. A. Cohen, N. A. Cooley, A. Murphy, J. Scutt and D. F. Wass, Chem. Commun., 2002, 858-859; (b) A. Bollmann, K. Blann, J. T. Dixon, F. M. Hess, E. Killian, H. Maumela, D. S. McGuinness, D. H. Morgan, A. Neveling, S. Otto, M. Overett, A. M. Z. Slawin, P. Wasserscheid and S. Kuhlmann, J. Am. Chem. Soc., 2004, 126, 14712-14713.

2 (a) K. Blann, A. Bollmann, J. T. Dixon, F. M. Hess, E. Killian, H. Maumela, D. H. Morgan, A. Neveling, S. Otto and M. J. Overett, Chem. Commun., 2005, 620-621; (b) M. J. Overett, K. Blann, A. Bollmann, J. T. Dixon, F. Hess, E. Killian, H. Maumela, D. H. Morgan, A. Neveling and S. Otto, Chem. Commun., 2005, 622-624; (c) P. R. Elowe, C. McCann, P. G. Pringle, S. K. Spitzmesser and J. E. Bercaw, Organometallics, 2006, 25, 5255-5260; (d) K. Blann, A. Bollmann, H. Debod, J. Dixon, E. Killian, P. Nongodlwana, M. Maumela, H. Maumela, A. McConnell and D. Morgan, J. Catal., 2007, 249, 244-249; (e) Z. Weng, S. Teo and T. S. Andy Hor, Dalton Trans., 2007, 3493-3498; (f) S. Kuhlmann, K. Blann, A. Bollmann, J. Dixon, E. Killian, M. Maumela, H. Maumela, D. Morgan, M. Pretorius, N. Taccardi and P. Wasserscheid, J. Catal., 2007, 245, 279-284; $(g)$ S. Sa, S. M. Lee and S. Y. Kim, J. Mol. Catal. A: Chem., 2013, 378, 17-21; (h) R. Liu, S. Xiao, X. Zhong, Y. Cao, S. Liang, Z. Liu, X. Ye, A. Shen and H. Zhu, Chin. J. Org. Chem., 2015, 35, 1861-1888.

3 (a) C. Bianchini, G. Giambastiani, I. G. Rios, G. Mantovani, A. Meli and A. M. Segarra, Coord. Chem. Rev., 2006, 250, 1391-1418; (b) T. Agapie, Coord. Chem. Rev., 2011, 255, 861-880; (c) D. S. McGuinness, Chem. Rev., 2011, 111, 2321-2341.

4 (a) J. T. Dixon, M. J. Green, F. M. Hess and D. H. Morgan, J. Organomet. Chem., 2004, 689, 3641-3668; (b) L. E. Bowen, M. Charernsuk and D. F. Wass, Chem. Commun., 2007, 2835-2837; (c) P. Crewdson, S. Gambarotta, M.-C. Djoman, I. Korobkove and R. Duchateau, Organometallics, 2005, 25, 5214-5216; (d) W. J. v. Rensburg, C. Grové, J. P. Steynberg, K. B. Star, J. J. Huyser and P. J. Steynberg, Organometallics, 2004, 23, 1207-1222.

5 (a) Y. Shaikh, J. Gurnham, K. Albahily, S. Gambarotta and I. Korobkov, Organometallics, 2012, 31, 7427-7433; (b) O. L. Sydora, T. C. Jones, B. L. Small, A. J. Nett, A. A. Fischer and M. J. Carney, ACS Catal., 2012, 2, 2452-2455; (c) Y. Yang, J. Gurnham, B. Liu, R. Duchateau, S. Gambarotta and I. Korobkov, Organometallics, 2014, 33, 5749-5757; (d) A. Alzamly, S. Gambarotta, I. Korobkov, M. Murugesu, J. J. Le Roy and P. H. Budzelaar, Inorg. Chem., 2014, 53, 6073-6081; (e) J. E. Radcliffe, A. S. Batsanov, D. M. Smith, J. A. Scott, P. W. Dyer and M. J. Hanton, ACS Catal., 2015, 5, 7095-7098.

6 (a) D. S. McGuinness, D. B. Brown, R. P. Tooze, F. M. Hess, J. T. Dixon and A. M. Z. Slawin, Organometallics, 2006, 25, 3605-3610; (b) D. S. McGuinness, P. Wasserscheid, W. Keim, C. Hu, U. Englert, J. T. Dixon and C. Grove, Chem. Commun., 2003, 334-335; (c) D. S. McGuinness, P. Wasserscheid, D. H. Morgan and J. T. Dixon, Organometallics, 2005, 24, 552-556; (d) S. S. Rozenel, W. A. Chomitz and J. Arnold, Organometallics, 2009, 28, 6243-6253.

7 M. E. Bluhm, O. Walter and M. Döring, J. Organomet. Chem., 2005, 690, 713-721.

8 Q. Liu, R. Gao, J. Hou and W. Sun, Chin. J. Org. Chem., 2013, 33, 808-814.

9 S. Liu, R. Pattacini and P. Braunstein, Organometallics, 2011, 30, 3549-3558.

10 (a) A. Alzamly, S. Gambarotta and I. Korobkov, Organometallics, 2013, 32, 7204-7212; (b) A. Alzamly, S. Gambarotta and I. Korobkov, Organometallics, 2013, 32, 7107-7115; (c) A. Alzamly, S. Gambarotta and I. Korobkov, Organometallics, 2014, 33, 1602-1607; (d) D. Gong, W. Liu, T. Chen, Z.-R. Chen and K.-W. Huang, J. Mol. Catal. A: Chem., 2014, 395, 100-107.

11 (a) R. Emrich, O. Heinemann, P. W. Jolly, C. Kru and G. P. J. Verhovnik, Organometallics, 1997, 16, 1511-1513; (b) H. Mahomed, Appl. Catal., A, 2003, 255, 355-359; (c) D. S. McGuinness, P. Wasserscheid, W. Keim, D. Morgan, J. T. Dixon, A. Bollmann, H. Maumela, F. Hess and U. Englert, J. Am. Chem. Soc., 2003, 125, 5272-5273; (d) W. J. v. Rensburg, J.-A. v. d. Berg and P. J. Steynberg, Organometallics, 2007, 26, 1000-1013; (e) J. Zhang, P. Braunstein and T. S. A. Hor, Organometallics, 2008, 27, 4277-4279; (f) S. Bhaduri, S. Mukhopadhyay and S. A. Kulkarni, J. Organomet. Chem., 2009, 694, 1297-1307; $(g)$ S. Peitz, N. Peulecke, B. R. Aluri, S. Hansen, B. H. Müller, A. Spannenberg, U. Rosenthal, M. H. AlHazmi, F. M. Mosa, A. Wöhl and W. Müller, Eur. J. Inorg. Chem., 2010, 1167-1171; (h) B. R. Aluri, N. Peulecke, S. Peitz, A. Spannenberg, B. H. Muller, S. Schulz, H. J. Drexler, D. Heller, M. H. Al-Hazmi, F. M. Mosa, A. Wohl, W. Muller and U. Rosenthal, Dalton Trans., 2010, 39, 7911-7920; (i) T. Beweries, C. Fischer, S. Peitz, V. V. Burlakov, P. Arndt, W. Baumann, A. Spannenberg, D. Heller and U. Rosenthal, J. Am. Chem. Soc., 2009, 131, 4463-4469.

12 (a) J. Skupinska, Chem. Rev., 1991, 91, 613-648;

(b) L. A. MacAdams, G. P. Buffone, C. D. Incarvito, 
J. A. Golen, A. L. Rheingold and K. H. Theopold, Chem. Commun., 2003, 1164-1165; (c) H. Sugiyama, G. Aharonian, S. Gambarotta, G. P. A. Yap and E. H. M. Budzelaar, J. Am. Chem. Soc., 2002, 124, 12268-12274; (d) G. Bhandari, Y. Kim, J. M. McFarland, A. L. Rheingold and K. H. Theopold, Organometallics, 1995, 14, 738-745; (e) C. Schulzke, D. Enright, H. Sugiyama, G. LeBlanc, S. Gambarotta and G. P. A. Yap, Organometallics, 2002, 21, 3810-3816.

13 (a) K. Albahily, V. Fomitcheva, S. Gambarotta, I. Korobkov, M. Murugesu and S. I. Gorelsky, J. Am. Chem. Soc., 2011, 133, 6380-6387; (b) K. Albahily, Y. Shaikh, E. Sebastiao, S. Gambarotta, I. Korobkov and S. I. Gorelsky, J. Am. Chem. Soc., 2011, 133, 6388-6395; (c) S. Licciulli, K. Albahily, V. Fomitcheva, I. Korobkov, S. Gambarotta and R. Duchateau, Angew. Chem., Int. Ed., 2011, 50, 2346-2349; (d) K. Albahily, V. Fomitcheva, Y. Shaikh, E. Sebastiao, S. I. Gorelsky, S. Gambarotta, I. Korobkov and R. Duchateau, Organometallics, 2011, 30, 4201-4210; (e) A. J. Rucklidge, D. S. McGuinness, R. P. Tooze, A. M. Z. Slawin, J. D. A. Pelletier, M. J. Hanton and P. B. Webb, Organometallics, 2007, 26, 2782-2787. There are some reports also discussed on relating with the $\mathrm{Cr}(\mathrm{II}) / \mathrm{Cr}$ (Iv) couple for the tri-/tetramerization catalysis, see: (f) J. Rabeah, M. Bauer, W. Baumann, A. E. C. McConnell, W. F. Gabrielli, P. B. Webb, D. Selent and A. Brückner, ACS Catal., 2013, 3, 95-102.

14 (a) T. Xu, Y. Mu, W. Gao, J. Ni, L. Ye and Y. Tao, J. Am. Chem. Soc., 2007, 129, 2236-2237; (b) K. H. Theopold, Eur. J. Inorg. Chem., 1998, 15-24.

15 (a) H. Zhu, K. Zhu, T. Zhu, G. Tan, Y. Li and H. Wan, CN Pat., 102585054, 2012. More recently, a ligand with the $\mathrm{NCN}_{-} \mathrm{C}_{6} \mathrm{H}_{4}-\mathrm{o}-\mathrm{P}(\mathrm{O}) \mathrm{Ph}_{2}$ scaffold was reported, see: (b) A. O. Tolpygin, T. A. Glukhova, A. V. Cherkasov, G. K. Fukin, D. V. Aleksanyan, D. Cui and A. A. Trifonov, Dalton Trans., 2015, 44, 16465-16474.

16 M. K. Cooper, J. M. Downs, P. A. Duckworth and E. R. T. Tiekink, Aust. J. Chem., 1992, 45, 595-609.

17 (a) F.-S. Liu, H.-Y. Gao, K.-M. Song, L. Zhang, F.-M. Zhu and Q. Wu, Polyhedron, 2009, 28, 1386-1392; (b) M. L. Rosenberg,
E. Langseth, A. Krivokapic, N. S. Gupta and M. Tilset, New J. Chem., 2011, 35, 2306-2313.

18 (a) B. Gao, X. Luo, W. Gao, L. Huang, S. M. Gao, X. Liu, Q. Wu and Y. Mu, Dalton Trans., 2012, 41, 2755-2763; (b) G. K. Cantrell, S. J. Geib and T. Y. Meyer, Organometallics, 1999, 18, 4250-4252; (c) C. J. Cooper, M. D. Jones, S. K. Brayshaw, B. Sonnex, M. L. Russell, M. F. Mahon and D. R. Allan, Dalton Trans., 2011, 40, 3677-3682.

19 (a) I. Y. Skobelev, V. N. Panchenko, O. Y. Lyakin, K. P. Bryliakov, V. A. Zakharov and E. P. Talsi, Organometallics, 2010, 29, 2943-2950; (b) A. Brückner, J. K. Jabor, A. E. C. McConnell and P. B. Webb, Organometallics, 2008, 27, 3849-3856.

20 (a) J. Wang, G. Tan, D. An, H. Zhu and Y. Yang, Z. Anorg. Allg. Chem., 2011, 637, 1597-1601; (b) J. Wang, D. An and H. Zhu, Chin. J. Struct. Chem., 2010, 29, 933-939.

21 (a) Z. Hao, B. Xu, W. Gao, Y. Han, G. Zeng, J. Zhang, G. Li and Y. Mu, Organometallics, 2015, 34, 2783-2790; (b) T. Holtrichter-Rößmann, I. Häger, C.-G. Daniliuc, R. Fröhlich, K. Bergander, C. Troll, B. Rieger, R. S. Rojas and E.-U. Würthwein, Organometallics, 2016, 35, 1906-1915.

22 A. Jabri, P. Crewdson, S. Gambarotta, I. Korobkov and R. Duchateau, Organometallics, 2006, 25, 715-718.

23 D. S. McGuinness, M. Overett, R. P. Tooze, K. Blann, J. T. Dixon and A. M. Z. Slawin, Organometallics, 2007, 26, 1108-1111.

24 (a) R. Walsh, D. H. Morgan, A. Bollmann and J. T. Dixon, Appl. Catal., A, 2006, 306, 184-191; (b) T. Jiang, Y. Ning, B. Zhang, J. Li, G. Wang, J. Yi and Q. Huang, J. Mol. Catal. A: Chem., 2006, 259, 161-165.

25 We have performed the catalytic reactions by using either $\mathrm{CrCl}_{3}(\mathrm{THF})_{3} / \mathrm{MAO}$ or $\mathrm{CrCl}_{2}(\mathrm{THF})_{2} / \mathrm{MAO}$ under the same conditions as those in entry 3 , which gave a little amount of polyethylene (see entries 1 and 2 in the Table 2).

26 W. Herwig and H. Zeiss, J. Org. Chem., 1958, 23, 1404-1404. 27 G. M. Sheldrick, Acta Crystallogr., Sect. A: Fundam. Crystallogr., 1990, 46, 467-473.

28 G. M. Sheldrick, SHELXL-97, Program for Crystal Structure Refinement, University of Göttingen, Göttingen, Germany, 1997. 